\title{
The Court of Justice and Treaty Revision: A Case of Strategic Leniency?
}

\author{
José Luis Castro-Montero, Edwin Alblas Arthur Dyevre $^{\ddagger} \quad$ Nicolas Lampach ${ }^{\S}$
}

\begin{abstract}
Students of EU judicial politics have debated the credibility of legislative override as constraint on the behaviour of the European Court of Justice. Yet because of the high political hurdles for the passage of treaty amendments, treaty revision has been dismissed as the "nuclear option", exceedingly effective but difficult to use and, therefore, unlikely to impact judicial decision making. However, when treaties are being renegotiated, the ability of member state governments to pass treaty amendments to either punish or reward the Court is greater. This, we argue, may induce the Court of Justice to display more leniency towards member states in cases coinciding with ongoing Treaty negotiations. To test this hypothesis we examine the outcome of all infringement cases adjudicated between 1961 and 2016. We find that the ECJ is significantly less likely to render adverse rulings in cases concomitant with the final, most salient stage of treaty negotiations. Our analysis suggests that the relationship between Treaty revision and judicial behaviour may be more nuanced than commonly assumed in the literature.
\end{abstract}

Keywords: Court of Justice; European Union; Multilevel Model; Bayesian Statistics JEL Classification: N44; C11; C50; D74

Acknowledgment Arthur Dyevre and Nicolas Lampach acknowledge financial support from ERC Starting Grant 638154 (EUTHORITY).

Jose Luis Castro-Montero and Edwin Albas collected the data and suggested a variant of the hypothesis presented in the paper. Arthur Dyevre and Nicolas Lampach conducted the statistical analysis and wrote the paper.

\footnotetext{
*, Universidad Andina Simón Bolívar, Law School; E-mail: j.l.castromontero1@gmail.com

$\dagger$ University College Dublin, Sutherland School of Law; E-mail: edwin.alblas@ucdconnect.ie.

¥Corresponding author: KU Leuven Faculty of Law, Centre for Legal Theory and Empirical Jurisprudence, 45 Tiensestraat, Leuven, Belgium; E-mail: arthur.dyevre@law.kuleuven.be; Phone: +32 16325387.

§, KU Leuven Faculty of Law, Centre for Legal Theory and Empirical Jurisprudence; E-mail: nicolas. lampach@kuleuven.be.
} 


\section{The Court of Justice and Treaty Revision: A Case of Strategic Leniency}

Students of EU judicial politics have debated the credibility of legislative override as constraint on the behaviour of the European Court of Justice. Yet because of the high political hurdles for the passage of treaty amendments, treaty revision has been dismissed as the "nuclear option", exceedingly effective but difficult to use and, therefore, unlikely to impact judicial decision making. However, when treaties are being renegotiated, the ability of member state governments to pass treaty amendments to either punish or reward the Court is greater. This, we argue, may induce the Court of Justice to display more leniency towards member states in cases coinciding with ongoing treaty negotiations. To test this hypothesis we examine the outcome of all infringement cases adjudicated between 1961 and 2016. We find that the ECJ is significantly less likely to render adverse rulings in cases concomitant with the final, most salient stage of treaty negotiations. Our analysis suggests that the relationship between treaty revision and judicial behaviour may be more nuanced than commonly assumed in the literature.

Keywords: Court of Justice; European Union; Multilevel Model; Bayesian Statistics JEL Classification: N44; C11; C50; D74 


\section{Introduction}

To what degree supranational judges are insulated from political pressure is a question that is central to the social science literature on international adjudication (Larsson and Naurin, 2016, Voeten, 2013). Do international courts respond to variations in levels of public support or political fragmentation in the same way as domestic courts? From the perspective of international relations, the behaviour of international courts raises a question that falls right in the middle of the discipline's main dividing line. Are international courts merely the agents of the states that created them, as theories inspired by intergovernmentalism claim? Or do they enjoy sufficient autonomy to disregard the preferences of member state governments, as alternative accounts of supranational governance maintain? In the EU judicial politics literature, these opposite views have mapped neatly into the two camps that have dominated the discussion over the European Court's political power (Pollack, 1997). Emphasising the primacy of the state, intergovernmentalist scholars have conceptualised the ECJ as an agent of national governments (Garrett, 1992, 1995). Neofunctionalists, meanwhile, have stressed the difficulty of passing override legislation as effectively insulating the Court from political constraints (Stone Sweet, 2010, Sweet and Brunell, 2012).

Looking at the briefs filed by national governments in proceedings before the ECJ, empirical studies have found some evidence that the preferences of state actors matter (Carrubba et al., 2008, Larsson and Naurin, 2016). The conclusiveness of this evidence is not undisputed (Sweet and Brunell, 2012). Striking about this debate, though, is that it concentrates on secondary legislation and the possibility for member states to override judicial determinations via qualified majority voting in the Council. The predominant view seems that secondary legislation is the only channel-save for noncompliance at the domestic implementation stage-through which member states can, if at all, influence the Court of Justice. ${ }^{1}$ treaty revision, because it requires unanimity, is not viewed as a viable tactic to curb the Court's power (Alter, 2001, Conant, 2002, Höpner and Schäfer, 2012, Kelemen, 2012, Mattli and Slaughter, 1998, Moravcsik, 1993, Scharpf, 2010, Stone Sweet and Brunell, 2013, Tallberg, 2002a). This view is shared by legal scholars (Conway, 2011, Davies, 2016). Mark Pollack's oft-cited remark on the logic of delegation in the EU governance system summarizes the conventional wisdom:

\footnotetext{
${ }^{1}$ Exceptions to the dominant view include Carrubba et al. (2008), Garrett and Weingast (1993) and Garrett, Kelemen, and Schulz (1998).
} 
"The threat of treaty revision is essentially the 'nuclear option'-exceedingly effective, but difficult to use-and is therefore a relatively ineffective and noncredible means of member state control."(Pollack, 1997, 118-9)

The present paper revisits this claim and takes issue with conventional wisdom. To be sure, there can be no gainsaying that the requirement of unanimity renders it difficult to use treaty revision to reverse unfavourable rulings and to discipline activist judges. However, European treaties have been revised on multiple occasions since the 1980s. During treaty negotiations, when member state governments bargain over the terms of a new institutional deal, their ability to alter the Court's formal powers is greater. Most treaty revisions have come with additional grants of power to the EU judiciary and, occasionally, with amendments overriding judicial determinations. This, we argue, creates an incentive for the ECJ to avoid antagonizing member state governments lest they may push courtcurbing measures or block jurisdiction-expanding proposals. We test this hypothesis by examining all infringement cases issued between 1961 and 2016. ${ }^{2}$ Applying Bayesian estimation, we find that the Court is significantly less likely to rule against member state governments when adjudication coincides with the late phase of treaty negotiations. We conclude that the relationship between treaty revision and judicial behaviour is more nuanced than commonly assumed in the literature.

\section{Judicial Behaviour and Political Fragmentation}

A rich body of social science research has linked judicial activism to legislative stability and political fragmentation (Bergara et al., 2003, Clark, 2009, Cooter and Ginsburg, 1996, Dyevre, 2010, Eskridge Jr, 1991, Garrett et al., 1998, Meernik and Ignagni, 1997, Owens, 2010, Sala and Spriggs, 2004, Segal et al., 2011, Tsebelis, 2002). Usually inspired by rationalist accounts of judicial behaviour, this literature portrays judges as strategic decision makers and insists that the degree of political autonomy of judicial institutions depends on the ease with which legislation can be passed. Political systems characterised by high political fragmentation, in which departures from the legislative status quo require the agreement of a large number of polarized veto players, are associated with greater legislative stability. Because laws, including constitutional laws, are difficult to change, courts operating in such systems are also thought to enjoy greater political autonomy. Some accounts of political behaviour explicitly grounded in rational choice, like veto player theory

\footnotetext{
${ }^{2}$ Infringement cases have also been discussed in the compliance literature (Börzel et al., 2010, Tallberg, 2002b). The focus of our study, however, is on judicial behaviour, not state compliance with EU policy.
} 
(Tsebelis, 2002), suggest that the opposition of a single veto player may suffice to avert a legislative attempt to rein in an activist court. This argument, or at least some variant of it, has been applied to both domestic and international institutions to explain variations in judicial assertiveness (Alter, 2008, Cooter and Ginsburg, 1996, Stone Sweet and Brunell, 2013, Voeten, 2013). In short, where veto players are few and the winset of the status is large, courts have a strategic incentive to defer to the preferences of legislators. Where veto players are many and the winset of the status quo small, by contrast, this incentive is absent and courts, accordingly, are expected to be more activist. The same mechanism has been invoked in research on ECJ decision making. Larsson and Naurin (2016) and Carrubba et al. (2008) use government observations in ECJ cases to explain variations in the pro-integration valence of judicial outcomes. Specifically, they posit that the number of government observations in support of a given outcome is interpreted by the Court as a cue for the probability of a legislative override. The closer this number gets to the threshold for qualified majority in the Council, the argument goes, the more restraint the ECJ is likely to display. That government preferences and the threat to pass override directives and regulations via the ordinary legislative procedure represent an effective constraint on ECJ judges is not a claim that has gone unchallenged. Sweet and Brunell (2012), in particular, has disputed the empirical findings of Carrubba et al. (2008), maintaining that cases where the number of government observations reaches the qualified majority threshold are exceedingly rare. One need not agree with Sweet and Brunell (2012) to understand that if the credibility of an override threat under qualified majority voting is contested, the claim that treaty reform under unanimity may spur strategic judicial restraint appears even more controversial. Nevertheless, we suggest that, given the frequency with which European Treaties have been changed over the past decades, the "nuclear option" analogy may be going too far. During treaty negotiations at least, member state preferences may exert a more constraining influence on the Court.

Another assumption habitually made in studies invoking strategic conceptions of judicial behaviour is that judges are primarily concerned with departures from the legislative status quo coming as a reaction to contentious rulings. What disciplines judges, in other words, is the prospect of override (Carrubba et al., 2008, Cooter and Ginsburg, 1996, Larsson and Naurin, 2016). Rarely discussed, by contrast, is the possibility that favourable legislative initiatives may also induce strategic restraint. Yet this is a consideration that seems especially relevant at treaty level in the EU context where treaty revision is at least as much about institution-building as it is about policy-making. We argue that the desire 
to facilitate the adoption of favourable treaty changes may in fact have an even greater impact on the conduct of ECJ judges than the threat of override.

\section{$3 \quad$ Strategic Leniency and the Treaty Revision Process}

\subsection{The Rigidity of the Treaty Amendment Procedure}

There is no gainsaying that European treaties are hard to change. Treaty revision requires the summoning of an Intergovernmental Conference (IGC) or a Convention, the unanimous agreement of all member state governments and, finally, ratification by each member state in accordance with its own domestic constitutional precepts (which, for some, includes approval by referendum). For those who favour change, these requirements create a huge collective action problem, which enlargement only works to amplify. The more countries join the EU, the more veto players have the capacity to block changes to the constitutional status quo. Adding another degree of constitutional rigidity is the heterogeneity of member state interests and preferences, which further reduces the set of amendment proposals apt to overcome the status quo (Finke, 2009).

The institutional hurdle resulting from this collective action problem is what, according to the prevailing wisdom, effectively insulates the European Court from political pressure ${ }^{3}$. If an ECJ doctrine is grounded in an interpretation of a treaty provision, member state governments can only reverse it by changing the treaty, which, most of the time, will prove impossible (Davies, 2016). European Treaties span hundreds of articles, providing the ECJ with a large menu of incomplete clauses to tether its doctrines to. Alec Stone Sweet and Thomas Brunell make this point in emphatic terms and insist that it warrants viewing international courts such as the ECJ as "trustees" rather than as agents of member states governments:

Put in strategic terms, a trustee court operates in an unusually permissive zone of discretion. The zone of discretion is determined by the sum of competences explicitly delegated to a court and possessed as a result of its own lawmaking, minus the sum of control instruments available for use by the principals to override the court or to curb it in other ways. The courts of the ECHR, the EU, and the WTO exercise compulsory jurisdiction over questions concerning state noncompliance; states are under a legal obligation to comply with

\footnotetext{
${ }^{3}$ See Alter (1998), Sweet and Brunell (1998, 69), Conant (2002, 43), Mattli and Slaughter (1998), Conway (2011), Pollack (2003) and Moravcsik (1993, 513-4)
} 
their rulings; and the decision rule governing override - unanimity-reduces the probability of reversal virtually to nil (Stone Sweet and Brunell, 2013, $65-6)$.

There is no dispute that member state governments have traditionally been divided over the ECJ's powers. Writing in the late 1990s, Karen Alter portrayed small states together with Germany as more supportive of a strong ECJ while France and the UK as more sceptical:

Small states have an interest in a strong EU legal system. In front of the ECJ, political power is equalized, and within the ECJ, small states have disproportionate voice, since each judge has one vote, and decisions are taken by simple majority. The Benelux states are unlikely to agree to anything they perceive will weaken the legal system's foundations and thus compromise their own interests. The small states are not alone in their defense of the ECJ. [...] Although sometimes critical of the ECJ, the German government is also a supporter of a European Rechtstaat. Germany and the Benelux countries tend to block attempts to weaken ECJ authority, and they try to extend its authority as the EU expands into new legal areas whenever the political possibility exists. Britain and France, on the other hand, block attempts to expand EU legal authority (Alter, 1998, 137).

Alter further observed that even if it strongly objects to an ECJ ruling, a member state will be hesitant to call for an IGC to pass an override amendment. Indeed, because any member state can add an item to the agenda of an IGC, a government may be reluctant to call an IGC lest the agenda gets out of control and the question of the ECJ's competences be swamped by other issues (Alter, 1998, 138).

What this suggests is that the ECJ need not worry about member states calling an IGC for the sole purpose of reversing judicial determinations they find objectionable. Nevertheless, the dominant view may exaggerate the collective action problem arising from the decision rule governing treaty change. Just as EU legislators do manage to pass legislation despite numerous veto points and high political fragmentation (König et al., 2012), unanimity has not made treaty change impossible. In fact, EU treaties have been revised on numerous occasions in the last three decades. Six major revisions have been agreed upon between 1986 and 2009 (SEA, Maastricht, Amsterdam, Nice, Constitutional and Lisbon Treaty, of which five were ratified and promulgated. EU legislators and national governments routinely employ logrolling to overcome legislative gridlock (Aksoy, 2012), 
creating package deals to form winning legislative coalitions (Kardasheva, 2013). In sum, rigidity should not be taken to imply impossibility. Moreover, although mobilizing support for a court-curbing amendment is likely to prove impossible in normal times, it is a goal that looks much easier to achieve when a treaty revision is already under way. Besides, the prospect of favourable treaty amendments may have a constraining effect on ECJ judges, too.

\subsection{Negotiation Dynamics and ECJ Authority}

During an ongoing IGC, a government wishing to either restrict or expand the ECJ's powers can add an item to that effect to the IGC's agenda. Even though governments may diverge on the merits of the Court's case law and desirable level of activism, the fact that governments simultaneously bargain over multiple issues, the ECJ being only one among many others, should actually work to increase the odds of such an amendment being actually adopted (Aksoy, 2012). A government can bring otherwise recalcitrant member states around to its position by means of logrolling and side payments, trading demands over the Court for concessions over other issues. ${ }^{4}$

Table 1 summarizes the Court's institutional gains and losses over the eight major treaties signed since 1951. All treaty revisions since 1951 appear to have been, on balance, favourable to the Court. Yet the pattern revealed by these reforms yield some important insights about the dynamics of treaty negotiations with regard to the Court.

Generally speaking, the Court, as ultimate interpreter of EU law, benefits, at least indirectly, from the expansion of the EU's remit. For example, when the Single European Act (SEA) granted the EU authority to pass environmental legislation, the ECJ ipso facto became the ultimate interpreter of the new treaty provision as well as of all resulting legislation. So the Court tends, in general, to profit from the EU's "competence creep". The Court's institutional gains, though, have not been uniform and have varied in magnitude from treaty to treaty. The Nice Treaty, for example, amounted to a modest expansion in judicial authority compared to the SEA or even Maastricht. Moreover, the transfer of new powers from domestic to EU institutions, however, has not always automatically translated into more powers for the EU judiciary. The Maastricht Treaty, for instance,

\footnotetext{
${ }^{4}$ Schneider and Cederman (1994) suggest that national governments may exploit information asymmetries over the domestic ratification process to extract concessions from other member states. Hug and König (2002) and König and Hug (2000) apply a similar two-level game logic to bargaining over treaty change and find empirical evidence that domestic constraints operate as costly signal structuring negotiation and ratification strategies.
} 
created a new intergovernmental pillar dealing with Justice and Home Affairs Policy but excluded it from the ECJ's jurisdiction.

Also appearing in Table 1 are treaty provisions that explicitly aimed to overrule rulings governments found unpalatable. The negotiations over the Maastricht Treaty led to the adoption of two protocols that figure among the most noted attempts to reverse ECJ doctrines by means of treaty revision. The Barber Protocol limited the retroactive effects of the ECJ Barber ruling, in which the Court had held that pension schemes specifying a different pension age for male and female workers violated the EEC Treaty ban on sex discrimination.

The Grogan Protocol, meanwhile, was adopted to assuage the fears of the Irish government after the the Court had ruled in Society for the Protection of the Unborn Child $v$ Grogan that abortion constituted a service in the sense of the EEC Treaty free movement guaranties (Curtin, 1992, Garrett et al., 1998). Another override amendment, Article 141(4) EC Treaty, was introduced by the Amsterdam Treaty to reverse the 1995 Kalanke ruling in which the ECJ rejected a German affirmative action measure as incompatible with the principle of equal treatment (Conant, 2002, 235).

The observed pattern of institutional gains and losses can be explained by the decision rule governing treaty change. Unanimity entails that every member state government wields a formal veto and, therefore, has the power to block a departure from the status quo. This holds for amendments purporting to expand ECJ authority as well as for amendments seeking to roll back its jurisdiction. As a result, for a government opposed to the Court, preventing the extension of the Court's authority to new domains is considerably easier than rolling it back in policy areas where it has already been asserted. This asymmetry is reflected in treaty reforms since Maastricht. The Maastricht Treaty added the Foreign and Security Policy together with the Justice and Home Affairs Policy to the EU's widening set of competences, but entirely excluded the ECJ from these new areas (Alter, 2001, 196). Then the Treaty of Amsterdam did grant the ECJ some review authority over Justice and Home Affairs. But pro-integration and Eurosceptic governments agreed on a compromise. Member states would be free to limit preliminary ruling references to courts of last instance or to allow all their courts to use the mechanism. With respect to asylum and immigration issues-a politically sensitive area-no choice was left and the treaty only allowed courts of last instance to request preliminary rulings (Due, 1998). 
Table 1: ECJ and Treaty Revisions, 1951-2009.

\begin{tabular}{|c|c|c|c|c|c|}
\hline Treaty & Procedural Change & $\begin{array}{l}\text { Grant of Power in Preexisting } \\
\text { Policy Areas }\end{array}$ & $\begin{array}{l}\text { Grant of Power in New } \\
\text { Policy Areas }\end{array}$ & $\begin{array}{l}\text { Restriction in Preexist- } \\
\text { ing Policy Areas }\end{array}$ & $\begin{array}{l}\text { Restriction in New Pol- } \\
\text { icy Areas }\end{array}$ \\
\hline Paris (1951) & $\begin{array}{l}\text { Power to annul ECSC acts; } \\
\text { power to issue preliminary } \\
\text { rulings; power to order } \\
\text { pecuniary compensation }\end{array}$ & NA & NA & NA & NA \\
\hline Rome (1957) & $\begin{array}{l}\text { Power to hear infringement } \\
\text { proceedings; Court stripped } \\
\text { of power to order pecuniary } \\
\text { compensation }\end{array}$ & No & $\begin{array}{l}\text { European Atomic Energy } \\
\text { Community; European } \\
\text { Economic Community }\end{array}$ & No & No \\
\hline SEA (1986) & $\begin{array}{l}\text { Creation of First Instance } \\
\text { Tribunal }\end{array}$ & No & $\begin{array}{l}\text { Jurisdiction expanded to } \\
\text { social cohesion; social pol- } \\
\text { icy; research and technolog- } \\
\text { ical development; environ- } \\
\text { ment }\end{array}$ & No & No \\
\hline $\begin{array}{l}\text { Maastricht } \\
(1992)\end{array}$ & $\begin{array}{l}\text { Power to impose fines in } \\
\text { infringement cases }\end{array}$ & No & $\begin{array}{l}\text { Jurisdiction expanded to } \\
\text { citizenship rights; educa- } \\
\text { tion; culture; public health; } \\
\text { consumer protection; trans- } \\
\text { European networks; indus- } \\
\text { trial policy; development } \\
\text { cooperation; tourism; civil } \\
\text { protection; energy; EMU }\end{array}$ & $\begin{array}{l}\text { Barber Protocol; Grogan } \\
\text { Protocol }\end{array}$ & $\begin{array}{l}\text { No jurisdiction over Com- } \\
\text { mon Foreign and Security } \\
\text { Policy (CFSP); Justice and } \\
\text { Home Affairs (JHA); and } \\
\text { suspension clause in treaty } \\
\text { on European Union }\end{array}$ \\
\hline
\end{tabular}


Table 2: ECJ and Treaty Revisions, 1951-2007, Continued.

\begin{tabular}{|c|c|c|c|c|c|}
\hline Treaty & Procedural Change & $\begin{array}{l}\text { Grant of Power in Preexisting } \\
\text { Policy Areas }\end{array}$ & $\begin{array}{l}\text { Grant of Power in New } \\
\text { Policy Areas }\end{array}$ & $\begin{array}{l}\text { Restriction in Preexist- } \\
\text { ing Policy Areas }\end{array}$ & $\begin{array}{l}\text { Restriction in New Pol- } \\
\text { icy Areas }\end{array}$ \\
\hline $\begin{array}{l}\text { Amsterdam } \\
(1997)\end{array}$ & $\begin{array}{l}\text { Power to review annul- } \\
\text { ment proceedings against } \\
\text { decisions and framework } \\
\text { decisions }\end{array}$ & $\begin{array}{l}\text { Jurisdiction (limited to referrals } \\
\text { from last instance courts) over } \\
\text { asylum and immigration and ju- } \\
\text { dicial cooperation in civil mat- } \\
\text { ters and part of Schengen acquis; } \\
\text { limited jurisdiction over police } \\
\text { cooperation and cooperation in } \\
\text { criminal matters }\end{array}$ & No & $\begin{array}{l}\text { Article 141(4) EC Treaty: } \\
\text { overrule Kalanke ruling }\end{array}$ & No \\
\hline Nice (2001) & No & $\begin{array}{l}\text { Jurisdiction over procedural as- } \\
\text { pects of suspension clause }\end{array}$ & No & No & No \\
\hline $\begin{array}{l}\text { Const. Treaty } \\
(2004)\end{array}$ & No & $\begin{array}{l}\text { Expansion of review authority over } \\
\text { asylum and immigration, judicial } \\
\text { cooperation in civil matters and } \\
\text { Schengen acquis; Court granted } \\
\text { limited jurisdiction over police } \\
\text { cooperation and cooperation in } \\
\text { criminal matter and some aspects } \\
\text { of CFSP }\end{array}$ & $\begin{array}{l}\text { Jurisdiction over Charter of } \\
\text { Fundamental Rights }\end{array}$ & No & No \\
\hline Lisbon (2007) & No & $\begin{array}{l}\text { Expansion of review authority over } \\
\text { asylum and immigration, judicial } \\
\text { cooperation in civil matters and } \\
\text { Schengen acquis; Court granted } \\
\text { limited jurisdiction over police } \\
\text { cooperation and cooperation in } \\
\text { criminal matter and some aspects } \\
\text { of CFSP }\end{array}$ & $\begin{array}{l}\text { Jurisdiction over Charter of } \\
\text { Fundamental Rights }\end{array}$ & No & No \\
\hline
\end{tabular}


In a similar fashion, the Nice Treaty conferred authority upon the Court to review the act by which, under Article 7 TEU, the Council may suspend the voting rights of a member state in case of human rights violations. But the review authority of the Court was limited to the purely procedural requirements of the provision. The Lisbon Treaty repeated this pattern, extending further the jurisdiction of the Court while simultaneously providing for exceptions and opt-outs. The authority of the ECJ was extended to some aspects of the Common Foreign and Security Policy. But, for this policy area at least, the absence of judicial review was clearly intended to remain the rule (Barents, 2010). The logic determined by unanimity also explains why most attempts to roll back the Court's jurisdiction have failed. During the negotiations on the Amsterdam Treaty, the British government made proposals that aimed at "clipping the Court's wings" (Alter, 2001, 197). One was to create an appeals procedure that would have forced the Court to reconsider a ruling in light of political displeasure. Another proposal would have placed a cap on liability damages the Court could impose on member states. Yet the proposals-inspired by Eurosceptic voices in the Conservative Party of then Prime Minister John Major-failed to gain support outside the UK (Alter, 1998). In the few instances where governments successfully overruled the Court, the legislative override was limited in scope. Even the Barber Protocol limited itself to depriving the Barber decision of retroactive effects.

From the perspective of the Court, this means that offending a member state government may come with a serious institutional cost if it happens while treaty negotiations are under way. In some cases, the risk will be that it spurs the slighted government to push for an override amendment, as occurred with the Irish government following the Grogan ruling. More frequently, though, EU judges may fear that the government might use its veto to block amendments they would like to see adopted. In other words, strategic leniency in the EU context may be motivated at least as much, if not more, by the desire to ease the adoption of authority-enhancing reforms as by the desire to avoid legislative reprisals.

\subsection{Salient Junctures in the Treaty Revision Process}

This said, treaty revisions are a long and complex affair, and there are good reasons to believe that not all phases of the revision process are equally important or salient to ECJ judges. Besides state actors, treaty revisions involve national and supranational groups and institutions, which commonly diverge along several dimensions, including the desirable depth of integration and the scope of majoritarian decision making (Beach, 2004, 
Christiansen et al., 2002, Falkner, 2002, Finke, 2009, Hug and König, 2002, Konig and Slapin, 2004, Slapin, 2008). In practice, with the exception of the Constitutional Treaty and the Charter of Fundamental Rights, which were prepared by a Convention composed of representatives of both national and EU institutions, negotiations on a new treaty are first conducted by bureaucrats. Remaining disagreements are then resolved by national leaders at the European summit closing the IGC, typically in marathon negotiations over a couple of days (and nights) (Beach and Mazzucelli, 2006). Once heads of government have settled on a deal, the signature follows; an event that, in turn, marks the beginning of the domestic ratification process. From the launch of the IGC to the signature, the whole revision process may span several years. In the case of Maastricht, the two parallel IGCs on Economic and Monetary Union and on Political Union were kick-started in December 1990. They concluded with the Maastricht summit held in December 1991 and the treaty was eventually signed on 7 February 1992. Similarly, the IGC that led to the Amsterdam revision was officially launched in March 1996. It closed with the European summit held in Amsterdam on 16-17 June 1997 and governments signed the new treaty on 2 October of the same year.

The ECJ does not have a seat at the negotiations table. Nor does it have an internal service or staff to monitor treaty negotiations. So we expect EU judges to be more responsive to the stages of the revision process that (a) attract greater public and media attention and (b) are perceived to be more decisive in terms of determining the actual content of the agreement. Dominated by working groups and position papers, the early, more bureaucratic phase of treaty negotiations is clearly less salient. It is also typically seen as less decisive. Likewise, once the negotiations are over, member state governments have an interest in seeing the agreed deal signed and ratified. Clearly, as far the content of treaty amendments is concerned, this phase is not decisive. So we should not expect the Court to worry that a member state might throw out the entire agreement for the loss of one or two infringement disputes. This leaves us with the last stage of the negotiations culminating in the European summit closing the IGC as the phase most likely to influence the Court. It is usually in this highly salient phase, in which heads of government and cabinet members are more intensively involved, that compromises are brokered and the central issues resolved (for SEA negotiations see Moravcsik (1991, 41-2); for the Nice Treaty see Tallberg $(2004,1013-7))$.

To the extent that matters related to the Court may be viewed as less critical than, say, voting weights in the Council, one may be inclined to think that these will be disposed 
of early on in the revision process. However, the Grogan Protocol shows that proposals running counter to the ECJ's institutional interests can be tabled very late into the negotiations. The Court handed out its ruling on 4 October 1991-just two months before the final European summit in Maastricht.

In view of these considerations, our hypothesis can be formulated as follows:

Strategic Leniency Hypothesis: The ECJ is less likely to rule against a member state government in cases adjudicated during the last stage of treaty negotiations.

\section{Data and Methodology}

\subsection{Infringement Proceedings}

To test the leniency hypothesis, we collect the outcome of all infringement rulings between 1961 and May 2017. Focusing on infringement proceedings has several advantages. First, assessing the outcome of infringement cases is straightforward. The interest and position of the defending member state is clear-we can safely assume that it wants to win. So too is the verdict of the Court, which either decides for or against the defending member state. In that respect, infringement cases are much easier to code than preliminary rulings. Preliminary rulings do not include a true case disposition and the Court of Justice may leave ample discretion to the referring court to decide how its jurisprudential pronouncements should be applied to the dispute at hand. Nor are governments usually parties in the lawsuits giving rise to the preliminary referral. Consequently, in order to establish whether a preliminary ruling runs counter to a government's policy preferences requires researchers to make some difficult judgement calls on the meaning of statements contained in briefs (when these are available) and ECJ opinions. No such problem exists with infringement rulings. Second, because the plaintiff in infringement proceedings is invariably the European Commission, we can rule out the effect of possible confounders such as differing levels of resources and familiarity with EU law-factors that can affect the outcome of preliminary rulings.

The fact that infringement cases can only be brought by the European Commission arguably raises the question of strategic timing. If the ECJ is really influenced by the treaty revision process and the Commission as a repeat player is aware of it, the Commission may deliberately delay action in cases that it is more eager to win or in cases with stronger merits. However, two factors make strategic timing unlikely. First, once a suit is filed, 
timing is controlled by the Court. On average, the ECJ hands down its ruling more than 18 months after the case has been filed, with median $=24$ months and SD $=12$ months. Second, as we will see below, monthly fluctuations in win rates make it hard for the European Commission's legal service to perceive the effect of treaty change.

Our dataset pulls together data from two separate data-collection efforts. The first, conducted by Clifford Carrubba and Matthew Gabel, gathered information on infringement proceedings decided between 1961 and 1999..$^{5}$ The second is an original dataset coding all infringement rulings issued over the period 2000-2017 ( $\mathrm{N}=1116)$ constructed by José Luis Castro-Montero and Edwin Albas. Our final dataset consists of 1857 infringement rulings.

Unlike Carrubba and Gabel who make the legal issue their unit of analysis, our quantity of interest is the case disposition. We adapted Carrubba and Gabel's data to our own coding rules and cross-checked it with the data on noncompliance gathered by Tanja Borzel and Carina Sprungk. ${ }^{6}$ Our variable of interest, Ruling, is coded 1 if the Court of Justice rules against the defending member state, and 0 if it rules in favour of the defending member state.

\subsection{Independent Variable: Treaty Negotiations}

Our independent variable is treaty negotiations. We only include major treaty revisions in our analysis. Accession treaties do formally count as treaty revisions. But, because these treaties do not modify the EU's institutional architecture nor the scope of the ECJ's powers, we exclude them from the analysis. This leaves us with the following list of institution-changing treaties signed after the introduction of the infringement procedure by the Rome Treaty: the Merger Treaty (signed in 1965), the Single European Act (signed in 1986), the Maastricht Treaty (signed in 1992), the Amsterdam Treaty (signed in 1998), the Charter of Fundamental Rights (signed in 2000), the Treaty of Nice (signed in 2001), the Constitutional Treaty (signed in 2004) and the Treaty of Lisbon (signed in 2007). Rejected by French and Dutch voters, the Constitutional Treaty has never been ratified, however it was signed, and it was in the ECJ's interest that it be signed and ratified. So we include it in our analysis. The Merger Treaty, whose scope was limited to merging institutions from the three Communities (ECSC, EEC and Euratom), is not habitually regarded as a major treaty revision. Nor is the Charter of Fundamental Rights, which

\footnotetext{
${ }^{5}$ See http://polisci.emory.edu/home/people/carrubba_CJEUd/ (accessed 3 May 2017) and European Court of Justice Rulings Database http://CJEUrulings.wustl.edu/ (accessed 3 May 2017).

${ }^{6}$ See http://www.infringement-db.jmce.org/Index.html (accessed 7 May 2017).
} 
was adopted as non-binding declaration before being incorporated in the Constitutional Treaty and, later, annexed to the Lisbon Treaty. In consequence, we do not include these two treaties in our main analysis. However, we report the results of model specifications including these two treaty revisions in the Supplementary Materials (see Table 7).

We test several operationalisations of the independent variable. First, we begin with a crude operationalisation, coding the years in which negotiations over a major treaty revision ended as one and otherwise as zero. This is a crude operationalisation because there are instances where treaty negotiations end in December and others where the final European summit is held in June or October. Using months is more precise than years. Yet it is hard to determine exactly which months matter purely on the basis of theory. Should we only count the month in which the final summit was held? Up to two months before? There is also the possibility that, while announced after the end of the negotiations, some rulings may in fact have been deliberated and decided before negotiations were over. To address this problem we report results for periods going from six months to one month before treaty signature. We expect periods including a greater proportion of observations close to the final stage of treaty negotiations to have a stronger effect on ECJ decisions. For some tests, we report estimates for four months to signature, a period chosen on the basis of the previous analysis. In addition, we consider the year of signature as an alternative operationalisation. ${ }^{7}$ Lastly, we test the effect of individual treaties using dummies based on the three operationlisations just described.

\subsection{Control Variables}

Based on previous literature on compliance (Börzel et al., 2010) and ECJ decision making (Arrebola et al., 2016, Carrubba and Gabel, 2014, Frankenreiter, 2017), we include the position of the Advocate General $(A G-E C J)$, the member state's political power as measured by the Shapley Shubik Index $(S S I)$ and public sector efficiency as measured by the Global Competitiveness Ranking (Efficiency) as control variables. ${ }^{8}$ Advocate General opinions have been found to be a significant predictor of ECJ decision making. In cases where an Advocate General was appointed and she/he issued an opinion, the Court tends to agree with the solution advocated in the opinion (Arrebola et al., 2016, Carrubba and

\footnotetext{
${ }^{7}$ In the Supplementary Materials we also report the results using the year the ratification process ended.

${ }^{8}$ We also tested a model including the number of domestic veto players as additional control. One could argue that the higher the number of veto players, the more difficult it will be for a government to introduce the treaty revision and to persuade other member states of the reform. Results are reported in the Supplementary Materials (see Figure 11).
} 
Gabel, 2014, Frankenreiter, 2017, Tridimas, 1997). The Shapley Shubik Index measures the proportion of times when a member state is pivotal under qualified majority voting in the EU legislative process. This measure of political power has been found to be positively and significantly correlated with adverse outcomes, implying that powerful member states are more likely to lose infringement cases (Börzel et al., 2010). Based on the state performance index from the Global Competitiveness Ranking 2007-2018, the third control captures the material and efficient management of resources of the public sector to ensure compliance. Greater public sector efficiency has been found to be associated with a lower probability that the ECJ rules against a member state government (Börzel et al., 2010). ${ }^{9}$ We provide details of the definition and operationalisation of these variables in Table 3 in Supplementary Materials. Unlike Larsson and Naurin (2016) and Carrubba et al. (2008), we do not control for government interventions, as these are very rare in infringement cases. $^{10}$

\subsection{Estimation Strategy}

The aim of our empirical analysis is to estimate the effect of treaty revision on judicial behaviour over time conditional on our controls. Our estimation strategy is designed to account for the dependencies that give the data its unbalanced, panel structure. Observations are not independent and member states represent a significant source of heterogeneityItaly, for example, is more likely to end on the losing side of an infringement case than any other member state. Bayesian multilevel modelling is well-suited to handle datasets with these characteristics (Dunson, 2001, Huang et al., 2006, Kruschke and Vanpaemel, 2015). In all our model configurations, each member state has its own separate random intercept, which in turn defines the baseline from which the effect of the explanatory variables on judicial outcomes is assessed. Also, using Bayesian inference comes with the considerable advantage that the output of our analysis-the posterior distribution for the coefficient of interest-conveys all the uncertainty left once the information from the empirical data is taken into account.

We set up our multilevel model to express within-variation at member state level $i$ and

\footnotetext{
${ }^{9}$ Because the inclusion of SSI and public sector efficiency is motivated by research that was concerned with elucidating the determinants of domestic compliance rather than the factors affecting judicial decision making, we report the results of our main model specifications without these controls in the Supplementary Materials (see Figure 7, 8 and 9). As it turns out, results are virtually identical.

${ }^{10}$ Looking at a subset $(\mathrm{N}=444)$ of infringement actions coded by Carrubba et al. (2008), Sweet and Brunell (2012) found that member state governments filed no observations or failed to take a weighted position for or against the defendant government in $93.5 \%$ of these cases.
} 
between-variation at time level $j$. The simplified multilevel logit model can be written as:

$$
\begin{aligned}
g\left(\text { Ruling }_{i j}^{*}\right) & =\beta_{0} \text { Intercept }+\beta_{1} \text { Major Treaty }_{i j}+\beta_{2} \text { AG-ECJ }_{i j} \\
& +\beta_{3} \text { SSI }_{i j}+\beta_{4} \text { Efficiency }_{i j} \\
g\left(\text { Ruling }_{i j}^{*}\right) & =\beta_{0} \text { Intercept }+\beta_{1} \text { SEA }_{i j}+\beta_{2} \text { Maastricht }_{i j}+\beta_{3} \text { Amsterdam }_{i j} \\
& +\beta_{4} \text { Nice }_{i j}+\beta_{5} \text { Constitution }_{i j}+\beta_{6} \text { Lisbon }_{i j} \\
& +\beta_{7} \text { AG-ECJ }_{i j}+\beta_{8} \text { SSI }_{i j}+\beta_{9} \text { Efficiency }_{i j}
\end{aligned}
$$

where Ruling ij $^{*}$ is the ECJ's decision to rule for or against a member state and $g()$ is the canonical link function of the Bernoulli distribution. Aside from relying on independent variable(s) and controls, the value of our binary dependent variable is also assumed to be determined by an unobserved random factor. Following the recommendations of Gelman (2006) and Bürkner (2016), we choose conservative priors for coefficients and intercepts.

Specifically, we set Student's t priors with $\nu=4, \mu=0$ and scale parameter $\sigma^{2}=2.5$ on the coefficients and half-Student's t priors with $\nu=3, \mu=0$ and scale parameter $\sigma^{2}=10$ on the intercepts. In the Supplementary Materials, we also report results using maximum likelihood estimation. MLE estimates are largely consistent with our Bayesian analysis.

\section{Results}

A look at descriptive statistics provides a first sense of the dynamics of infringement proceedings. Infringement litigation really took off in the early 1980s-beforehand the Commission seldom brought action against member states (Figure 1). Infringement proceedings then peaked in the last decade and declined after 2010.

National governments do not usually fare well in infringement cases. Consistent with previous research on ECJ decision making (Carrubba et al., 2008, Sweet and Brunell, 2012, 1998, 2004), our data shows that the Commission wins close to $90 \%$ of the cases it brings before the Court. The Commission's high success rate-and, thus, the poor performance overall of member state governments-can be readily explained by the fact that the Commission is a repeat player who simultaneously acts as gatekeeper to the Court. 


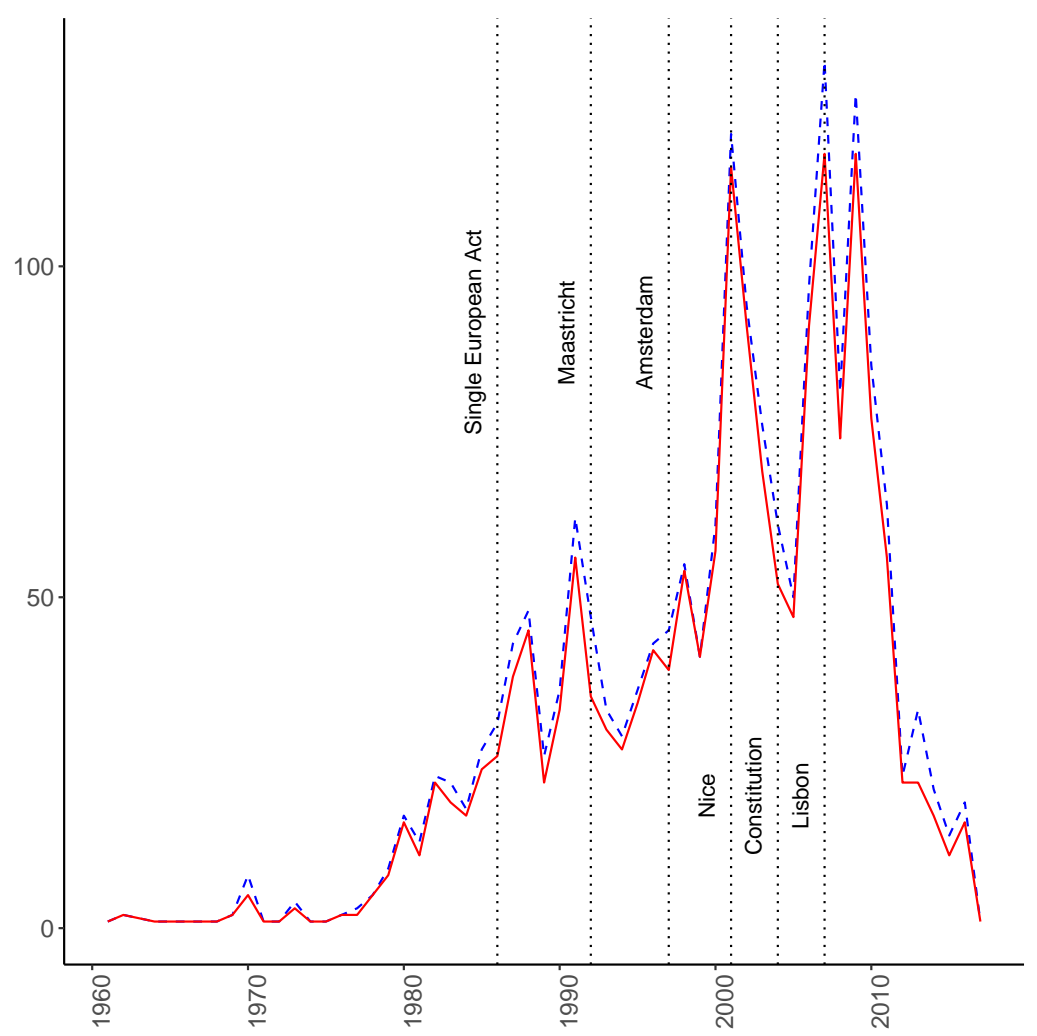

Figure 1: Infringement proceedings and proportion of rulings against national governments, 1961-2016. The dotted line (blue) denotes the total number of cases; the solid line (red) denotes the total number of rulings against member states.

Month-to-month success rates exhibit wide and irregular fluctuations (Figure 2). This suggests that the impact of treaty change on judicial outcomes, if any, is not immediately discernible. Thus, assuming that the hypothesised effect exists, we cannot be sure that the European Commission's legal service will have noticed it.

Another striking statistic is the level of agreement between the Advocate General and the Court. In $70.8 \%(\mathrm{n}=1313)$ of the cases in our dataset the Advocate General issued an opinion. In 93.9\% ( $\mathrm{n}=1233)$ of these, the Court agreed with the opinion of the Advocate General. Only in $6.1 \%(\mathrm{n}=80)$ of the cases did the Court diverge. Advocate General opinions, when present, thus constitute a strong predictor of ECJ decision making in infringement disputes.

Estimates for our Bayesian multilevel logistic models were computed by running 12000 stationary iterations, burning the first 2000 as warm-up iterates. ${ }^{11}$

\footnotetext{
${ }^{11}$ Data analysis was carried out using R packages 'brms' v1.6.1 (Bürkner, 2016), 'AER' v1.2-5 (Zeileis and Kleiber, 2008) and 'lme4' v1.1-12 (Bolker et al., 2009).
} 


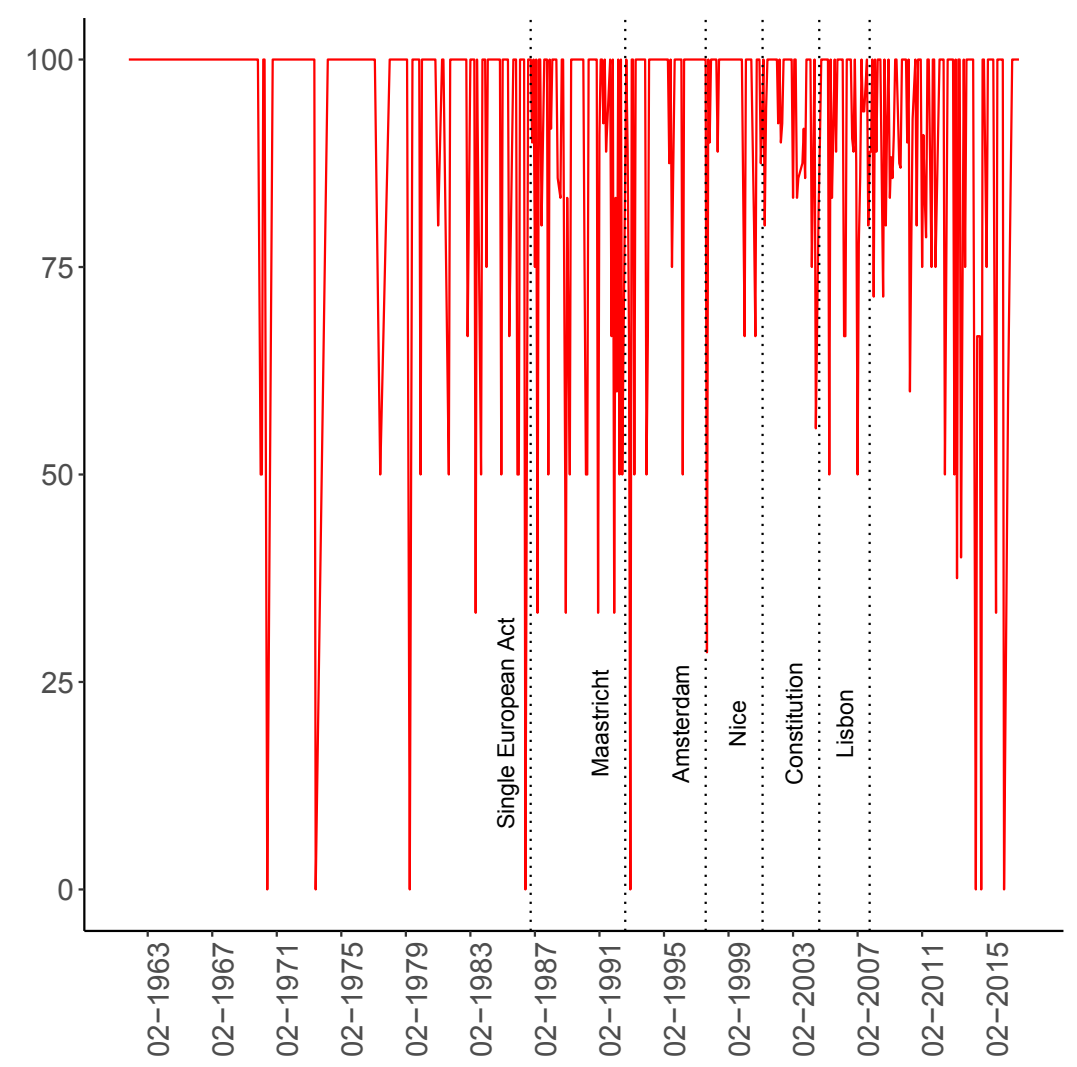

Figure 2: Proportion of rulings against member State governments by month, 1961-2017. Dotted lines denote end of treaty negotiations.

As a first approximation, Figure 3 shows coefficient estimates of equation 1 using year of signature (Test 1), year coinciding with negotiations ending (Test 2) and four months before signature (Test 3) as operationalisation of our independent variable. Posterior means are negative for all three tests but only significant for Test 1 and Test 3 (confidence intervals do not include zero). As we mentioned previously, negotiations sometimes end in one year while the treaty gets signed the following one. Since less than two months may separate the two events, it could be that year of signature (Test 1) captures the effect of decisions deliberated during negotiations but announced a month or two later. 


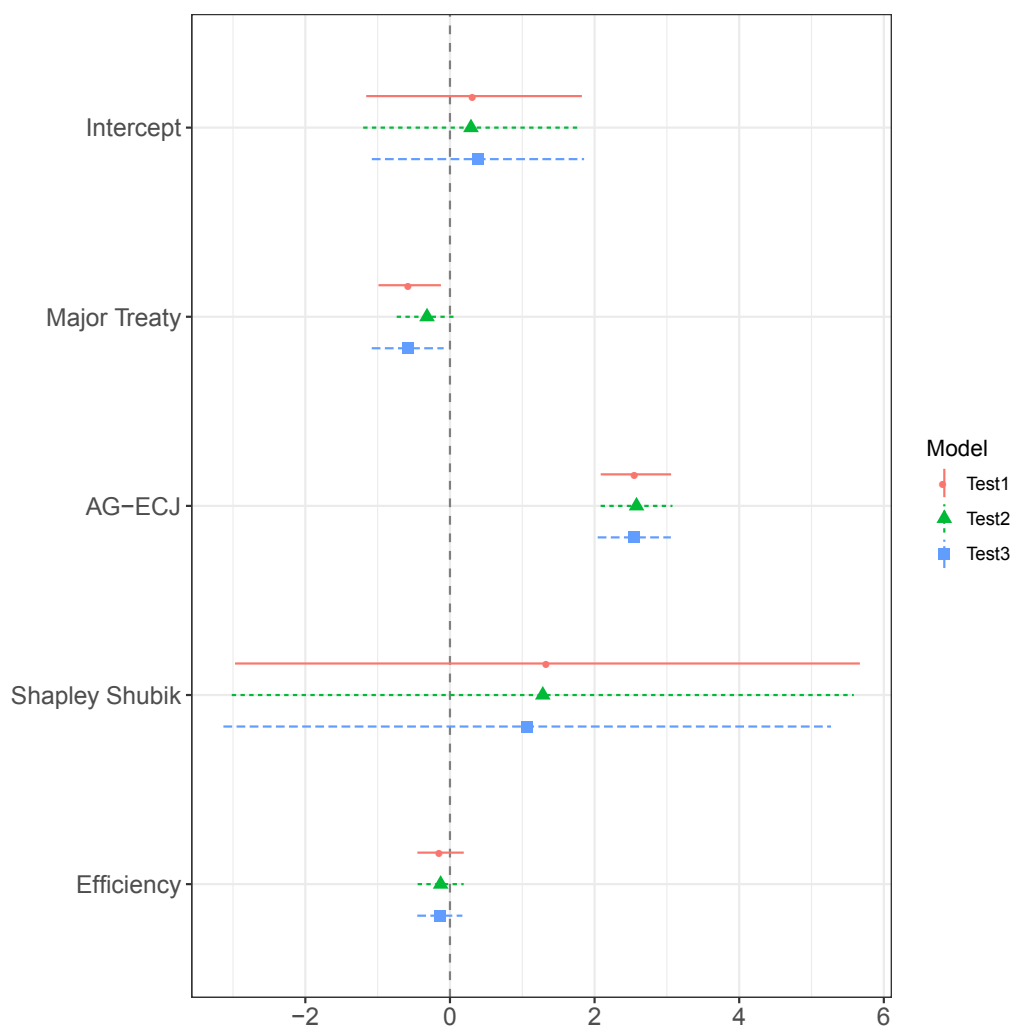

Figure 3: Estimates of equation (1) for three operationalisations of independent variable Major Treaty. Test 1 uses the year marking treaty signature. Test 2 the year marking the end of treaty negotiations. Test 3 the four-month period to signature. Plot shows posterior mean and $95 \%$ confidence interval.

As said above, operationalising the effect of treaty negotiations on judicial decision making by simply looking at the year in which the treaties were ratified or signed is excessively crude. On the other hand, using delimiting a four month period before signature (Test 3) may seem arbitrary. In order to better assess the effect of treaty negotiations on judicial behaviour and show how we narrowed down on this phase, Figure 4 reports the coefficient estimates for Major Treaty of six regressions using different operationalisations of this variable, ranging from six months to one month prior to treaty signature. Save for the last period (one month to signature), all these measures include rulings announced in months coinciding with the end of treaty negotiations. The grey stripes denote the months in which treaty negotiations ended. (As it turns out, treaty negotiations ended either in month 4 or month 2 before signature.) As can be seen, the posterior distribution of coefficients for six and five months include zero. So too does the posterior distributions for one month. In the end, only the coefficients for four, three and two months to signature come out as significant (upper bound of $95 \%$ confidence interval does not include zero). 


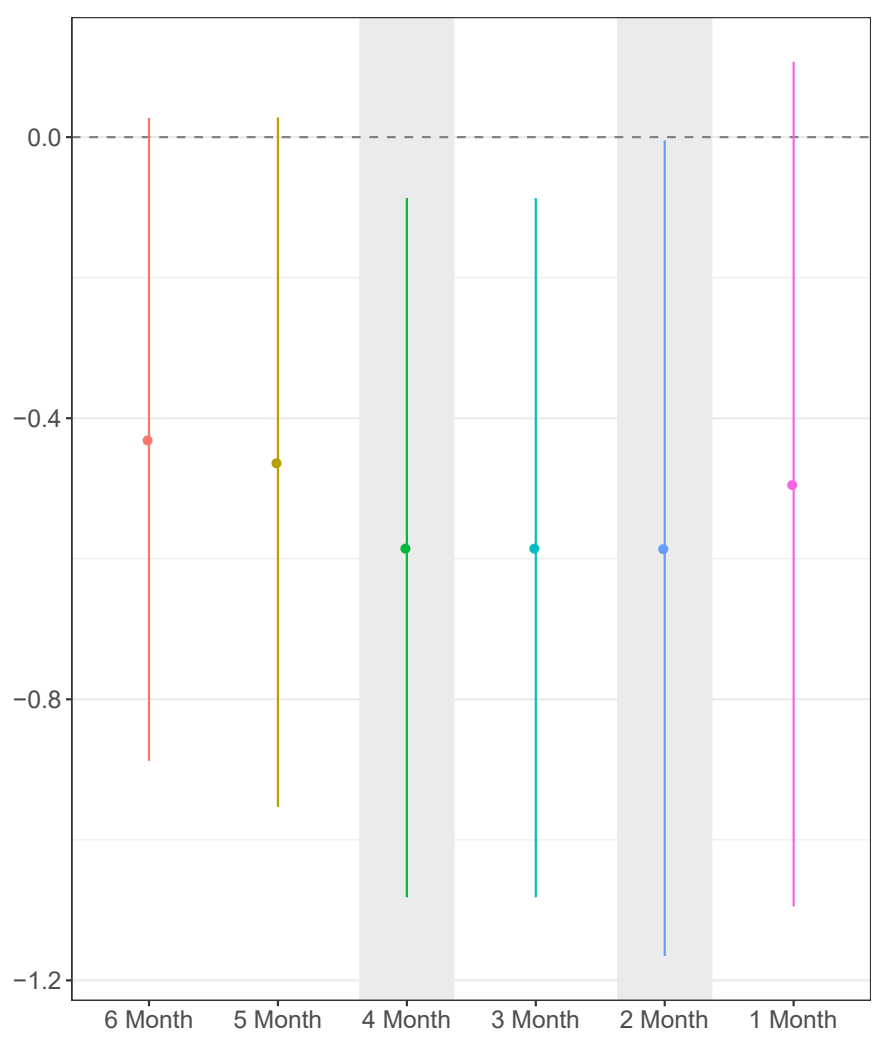

Figure 4: Posterior coefficient estimates for Major Treaty measured in months to treaty signature. Thick horizontal grey stripes denote month in which negotiations ended. Dots denote mean of posterior distribution, bars $95 \%$ confidence interval.

These results lend support to the Strategic Leniency Hypothesis. They imply that treaty negotiations induce greater deference towards national governments only when adjudication is sufficiently close to the final phase of negotiations. Illustrated in Figure 5 are the prior and posterior distributions of coefficients for the three main operationalisations of our explanatory variable: year of signature (Test 1, panel 9a), year coinciding with end of treaty negotiations (Test 2, panel $9 \mathrm{~b}$ ) and the four-month period prior to signature (Test 3, panel 9c). 


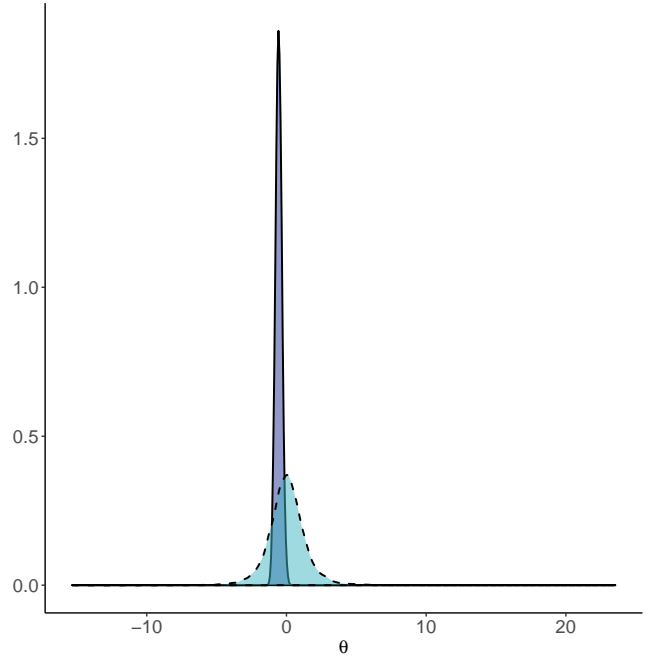

(a) Year treaty signature (Test 1)

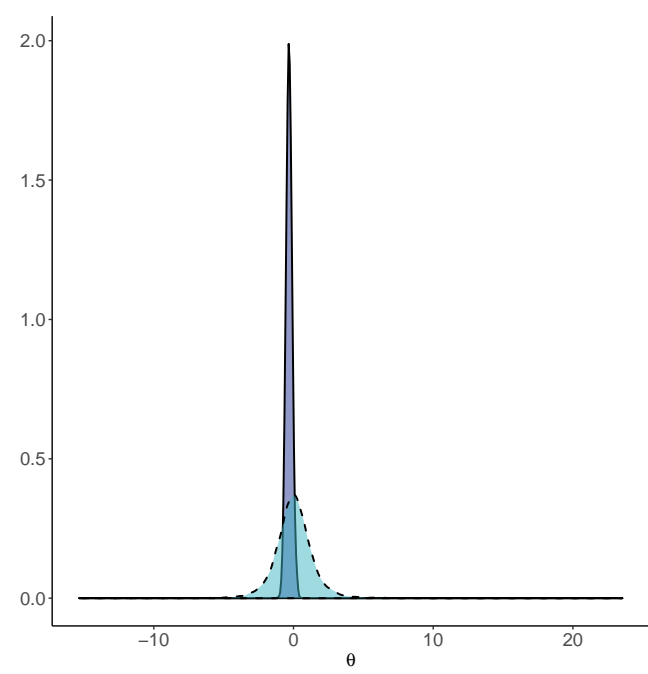

(b) Year negotiations end (Test 2)

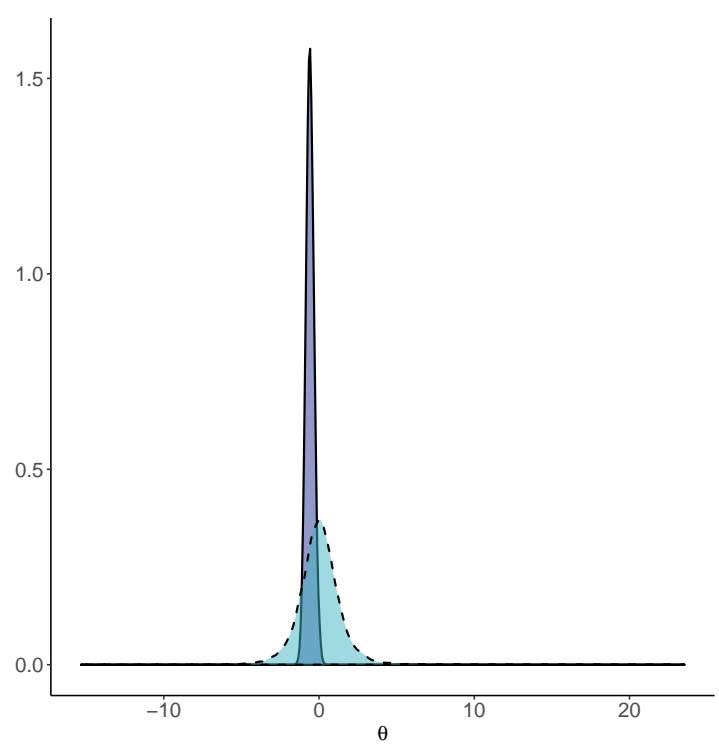

(c) Four months to treaty signature (Test 3)

Figure 5: Comparison of posterior and prior distribution of estimated effect of treaty revision on probability to rule against member state governments. The three panels correspond to the three main operationalisations of our independent variable. Dashed curve denotes prior distribution. 
A noted advantage of Bayesian analysis over frequentist methods is that it gives us a clear measure of the degree of confidence we can have in our estimates given our data and priors. The marked contrast between our conservative priors and our posterior distribution in panel 9c suggests that our data speaks loudly enough.

Moreover, most coefficient values in the posterior distribution are close to the mean, implying that we can have a high degree of confidence about the true value of the coefficient. Substantively, this means that we can be reasonably confident that judicial behaviour is influenced by the last phase of treaty negotiations. To give a sense of the effect size, the posterior mean for Test 3 is -0.584 . This can be interpreted as the odds of the Court ruling against a member state government is $44 \%$ lower when adjudication coincides with the final stage of treaty negotiations.

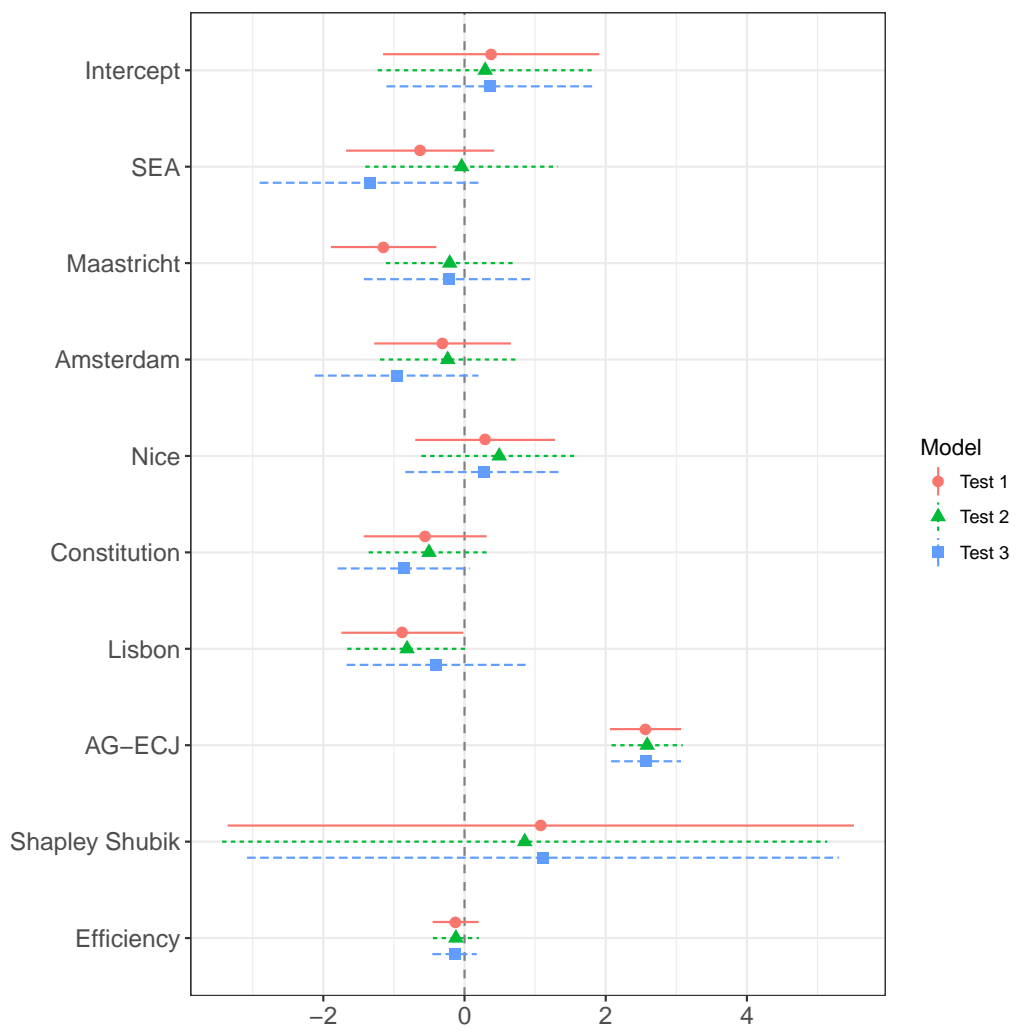

Figure 6: Estimates of equation (2). Plot shows posterior mean and $95 \%$ confidence interval for models with different operationalisations of the independent variables. Test 1 uses the year marking treaty signature. Test 2 the year marking the end of treaty negotiations. Test 3 the four-month period to signature.

Turning to the impact of individual treaties, Figure 6 shows that, save for the Nice Treaty, posterior means are consistently negative for all treaty revisions. Yet confidence intervals all include zero. That treaties considered individually are not significant is not 
surprising for two reasons. First, there is a considerable imbalance between the number of observations exposed to the treatment variable (the individual treaty revision) and the observations that are not (that is, all other observations, including those coinciding with the negotiations of other treaties). Second, even if the Court renders fewer adverse rulings in cases concomitant with a particular treaty revision, member states will still lose some cases during that period. Hence the difference in likelihood between the individual revision and all other periods is insufficient to offset the fact that only a limited number of observations coincide with the revision of a particular treaty. In sum, there is simply too little information to update the model's prior beliefs.

Finally, with regard to the control variables, $A G$-ECJ is, as expected, positive and highly significant across all model specifications. ${ }^{12}$ In contrast to Börzel et al. (2010), though, we find no significant effect for political power and public sector efficiency.

\section{Conclusion}

We argue that in years coinciding with treaty revisions the ECJ has incentives to be more lenient towards member states. To avert override amendments and to facilitate the adoption of authority-enhancing changes, the ECJ has an incentive to defer to national governments when adjudication coincides with ongoing treaty negotiations. Our empirical analysis shows that the Court is, indeed, more lenient when the timing of its rulings is close to the European summit marking the end of an IGC. The evidence we find for strategic leniency suggests that the relationship between treaty revision and ECJ decision is more nuanced than habitually understood. On the one hand, our findings appear to imply that the nuclear option analogy may overstate the difficulty of using treaty revision as a disciplinary device. Treaty revision is not a rare event. There have been six major treaty reforms since 1985. On each of these occasions member state governments had the opportunity to table and vote amendments to respond to the Court's jurisprudence. In some instances, this had led to the passage of override amendments, although, on the whole, new treaties have mostly benefited the Court. As we have tried to demonstrate, both the carrot of authority-strengthening proposals and the stick of authority-weakening amendments may induce the ECJ to pay greater heed to the preferences of its principals during negotiations over a new treaty. On the other hand, the fact that concomitance with treaty negotiations induces heightened judicial restraint implies that in normal times-that

\footnotetext{
${ }^{12}$ Our main findings hold when estimating the same models without the variable Advocate General (See Table ?? in Supplementary Materials.
} 
is, outside the context of a co-occurring IGC-the ECJ feels safe to ignore member state preferences. So the Court is clearly not an agent that member states can easily rein in. Yet, at the same time, the nuclear-weapon analogy and the trustee model expounded by scholars like Stone Sweet and Brunell (2013) seem to excessively underplay the effect of re-contracting on judicial behaviour. The implications of our findings potentially go beyond the ECJ. Amendment procedures under other international legal regimes bear little difference to that in place in the EU. So it is possible that in these regimes, too, international judges alter their behaviour when adjudication is concomitant with treaty change.

To be sure, our study has its limitations. While we are confident that our results are not the effect of strategic timing on the part of the Commission, our analysis cannot entirely rule out strategic timing on the part of the Court. It could be that the Court strategically schedules weaker cases so as to make their resolution coincide with the final stage of negotiations. It would still be an illustration of strategic judicial manoeuvring. Going forward, though, researchers may want to find a way to assess this alternative explanation. Similarly, we focused on infringement cases, in part, because they are easier to analyse. Future researchers might want to determine whether the argument also applies to preliminary rulings. There is also room to improve our understanding of the timing of judicial deliberations, as there is to explore how the saliency of the revision process in the media (which is probably where ECJ judges and staff get most of their information about treaty change) affects the behaviour of the Court. In that sense, our results can be viewed-and it is one of the advantages of Bayesian approaches-as providing plausible priors for future research on the interplay between treaty revision and adjudication. 


\section{References}

Aksoy, D. (2012). Institutional arrangements and logrolling: Evidence from the european union. American Journal of Political Science 56(3), 538-552.

Alter, K. J. (1998). Who are the "masters of the treaty"?: European governments and the european court of justice. International organization 52(1), 121-147.

Alter, K. J. (2001). Establishing the supremacy of European law: The making of an international rule of law in Europe. Oxford University Press Oxford.

Alter, K. J. (2008). Agents or trustees? international courts in their political context. European Journal of International Relations 14(1), 33-63.

Arrebola, C., A. J. Mauricio, and H. J. Portilla (2016). An economic analysis of the influence of the advocate general on the court of justice of the european union. Cambridge J. Int'l \& Comp. L. 5, 82.

Barents, R. (2010). The court of justice after the treaty of lisbon. Common Market Law Review 47, 709.

Beach, D. (2004). The unseen hand in treaty reform negotiations: the role and influence of the council secretariat. Journal of European Public Policy 11(3), 408-439.

Beach, D. and C. Mazzucelli (2006). Leadership in the big bangs of European integration. Springer.

Bergara, M., B. Richman, and P. T. Spiller (2003). Modeling supreme court strategic decision making: The congressional constraint. Legislative Studies Quarterly 28(2), $247-280$.

Bilbao, J. M., J. R. Fernandez, N. Jiménez, and J. J. Lopez (2002). Voting power in the european union enlargement. European Journal of Operational Research 143(1), $181-196$.

Bolker, B. M., M. E. Brooks, C. J. Clark, S. W. Geange, J. R. Poulsen, M. H. H. Stevens, and J.-S. S. White (2009). Generalized linear mixed models: a practical guide for ecology and evolution. Trends in ecology $\mathcal{E}$ evolution 24(3), 127-135.

Börzel, T. A., T. Hofmann, D. Panke, and C. Sprungk (2010). Obstinate and inefficient: Why member states do not comply with european law. Comparative Political Studies 43(11), 1363-1390. 
Bürkner, P.-C. (2016). brms: An r package for bayesian multilevel models using stan. Journal of Statistical Software 80(1), 1-28.

Carrubba, C. J., M. Gabel, and C. Hankla (2008). Judicial behavior under political constraints: Evidence from the european court of justice. American Political Science Review 102(4), 435-452.

Carrubba, C. J. and M. J. Gabel (2014). International courts and the performance of international agreements: A general theory with evidence from the European Union. Cambridge University Press.

Christiansen, T., G. Falkner, and K. E. Jørgensen (2002). Theorizing eu treaty reform: beyond diplomacy and bargaining. Journal of European Public Policy 9(1), 12-32.

Clark, T. S. (2009). The separation of powers, court curbing, and judicial legitimacy. American Journal of Political Science 53(4), 971-989.

Conant, L. J. (2002). Justice contained: law and politics in the European Union. Cornell University Press.

Conway, G. (2011). Recovering a separation of powers in the european union. European Law Journal 17(3), 304-322.

Cooter, R. D. and T. Ginsburg (1996). Comparative judicial discretion: An empirical test of economic models. International Review of Law and Economics 16(3), 295-313.

Curtin, D. (1992). Case c-159/90, the society for the protection of unborn children ireland ltd v. grogan, judgment of 4 october 1991. Common Market Law Review 29(3), 585-603.

Davies, G. (2016). The european union legislature as an agent of the european court of justice. JCMS: Journal of Common Market Studies 54(4), 846-861.

Due, O. (1998). Impact of the amsterdam treaty upon the court of justice. Fordham Int'l LJ S48 22.

Dunson, D. B. (2001). Commentary: practical advantages of bayesian analysis of epidemiologic data. American journal of Epidemiology 153(12), 1222-1226.

Dyevre, A. (2010). Unifying the field of comparative judicial politics: towards a general theory of judicial behaviour. European Political Science Review 2(2), 297-327.

Eskridge Jr, W. N. (1991). Reneging on history-playing the court/congress/president civil rights game. Cal. L. Rev. 79, 613 . 
Falkner, G. (2002). Eu treaty reform as a three-level process. Journal of European Public Policy 9(1), 1-11.

Finke, D. (2009). Challenges to intergovernmentalism: An empirical analysis of eu treaty negotiations since maastricht. West European Politics 32(3), 466-495.

Frankenreiter, J. (2017). The politics of citations at the ecj-policy preferences of eu member state governments and the citation behavior of judges at the european court of justice. Journal of Empirical Legal Studies 14(4), 813-857.

Garrett, G. (1992). International cooperation and institutional choice: the European Community's internal market. International Organization, 533-560.

Garrett, G. (1995). The politics of legal integration in the European Union. International Organization 49, 171-171.

Garrett, G., R. D. Kelemen, and H. Schulz (1998). The european court of justice, national governments, and legal integration in the european union. International Organization 52(1), 149-176.

Garrett, G. and B. R. Weingast (1993). Ideas, interests and institutions: Constructing the ec's internal market. pp. 149-176. Cornell University Press.

Gelman, A. (2006). Prior distributions for variance parameters in hierarchical models (comment on article by browne and draper). Bayesian analysis 1(3), 515-534.

Höpner, M. and A. Schäfer (2012). Embeddedness and regional integration: Waiting for polanyi in a hayekian setting. International Organization 66(3), 429-455.

Huang, Y., D. Liu, and H. Wu (2006). Hierarchical bayesian methods for estimation of parameters in a longitudinal hiv dynamic system. Biometrics 62(2), 413-423.

Hug, S. and T. König (2002). In view of ratification: Governmental preferences and domestic constraints at the amsterdam intergovernmental conference. International Organization 56(2), 447-476.

Kardasheva, R. (2013). Package deals in eu legislative politics. American Journal of Political Science 57(4), 858-874.

Kelemen, R. D. (2012). The political foundations of judicial independence in the european union. Journal of European Public Policy 19(1), 43-58. 
König, T., T. Dannwolf, and B. Luetgert (2012). Eu legislative activities and domestic politics. In The Europeanization of Domestic Legislatures, pp. 21-37. Springer.

König, T. and S. Hug (2000). Ratifying maastricht: Parliamentary votes on international treaties and theoretical solution concepts. European Union Politics 1(1), 93-124.

Konig, T. and J. Slapin (2004). Bringing parliaments back in: The sources of power in the european treaty negotiations. Journal of Theoretical Politics 16(3), 357-394.

Kruschke, J. K. and W. Vanpaemel (2015). Bayesian estimation in hierarchical models. The Oxford handbook of computational and mathematical psychology, 279-299.

Larsson, O. and D. Naurin (2016). Judicial independence and political uncertainty: how the risk of override affects the court of justice of the eu. International Organization $70(2), 377-408$.

Mattli, W. and A.-M. Slaughter (1998). Revisiting the European Court of Justice. International Organization 52(01), 177-209.

Meernik, J. and J. Ignagni (1997). Judicial review and coordinate construction of the constitution. American Journal of Political Science, 447-467.

Moravcsik, A. (1991). Negotiating the single european act: national interests and conventional statecraft in the european community. International organization 45(1), 19-56.

Moravcsik, A. (1993). Preferences and power in the european community: a liberal intergovernmentalist approach. JCMS: Journal of Common Market Studies 31(4), 473-524.

Owens, R. J. (2010). The separation of powers and supreme court agenda setting. American Journal of Political Science 54(2), 412-427.

Pollack, M. A. (1997). Delegation, agency, and agenda setting in the european community. International organization 51(1), 99-134.

Pollack, M. A. (2003). The engines of European integration: delegation, agency, and agenda setting in the EU. OUP Oxford.

Sala, B. R. and J. F. Spriggs (2004). Designing tests of the supreme court and the separation of powers. Political Research Quarterly 57(2), 197-208.

Scharpf, F. W. (2010). The asymmetry of european integration, or why the eu cannot be a 'social market economy'. Socio-economic review 8(2), 211-250. 
Schneider, G. and L.-E. Cederman (1994). The change of tide in political cooperation: A limited information model of european integration. International Organization 48(4), 633-662.

Segal, J. A., C. Westerland, and S. A. Lindquist (2011). Congress, the supreme court, and judicial review: Testing a constitutional separation of powers model. American Journal of Political Science 55(1), 89-104.

Slapin, J. B. (2008). Bargaining power at europe's intergovernmental conferences: testing institutional and intergovernmental theories. International Organization 62(1), 131162.

Stone Sweet, A. (2010). The European Court of Justice and the judicialization of EU governance. Living Reviews in EU Governance.

Stone Sweet, A. and T. L. Brunell (2013). Trustee courts and the judicialization of international regimes: The politics of majoritarian activism in the european convention on human rights, the european union, and the world trade organization. Journal of Law and Courts 1(1), 61-88.

Sweet, A. S. and T. Brunell (2012). The european court of justice, state noncompliance, and the politics of override. American Political Science Review 106(1), 204-213.

Sweet, A. S. and T. L. Brunell (1998). The european court and the national courts: A statistical analysis of preliminary references, 1961-95. Journal of European Public Policy 5(1), 66-97.

Sweet, A. S. and T. L. Brunell (2004). The judicial construction of Europe, Volume 4. Wiley Online Library.

Tallberg, J. (2002a). Delegation to supranational institutions: why, how, and with what consequences? West European Politics 25(1), 23-46.

Tallberg, J. (2002b). Paths to compliance: Enforcement, management, and the european union. International organization 56(3), 609-643.

Tallberg, J. (2004). The power of the presidency: Brokerage, efficiency and distribution in eu negotiations. JCMS: Journal of Common Market Studies 42(5), 999-1022.

Tridimas, T. (1997). Role of the advocate general in the development of community law: Some reflections, the. Common Market L. Rev. 34, 1349. 
Tsebelis, G. (2002). Veto players: How political institutions work. Princeton University Press.

Voeten, E. (2013). International judicial independence. pp. 421-44. Cambridge University Press.

World Economic Forum (2017). The global competitiveness report 2017-2018. https:// Www. weforum.org/reports/the-global-competitiveness-report-2017-2018 (accessed on 11/09/2017).

Zeileis, A. and C. Kleiber (2008). Aer: applied econometrics with r. $R$ package version 0.9-0, URL http://CRAN. R-project. org/package $=$ AER. 


\section{Supplementary materials}

Table 3: List of variables

\begin{tabular}{|c|c|c|c|}
\hline Variable name & Explanation & Type of data & Source \\
\hline Ruling $_{i, j}$ (Dependent variable) & $\begin{array}{l}\text { Dummy variable which takes the value one if the CJEU ruled } \\
\text { against a member state } i \text { in year } j \text { and zero otherwise }\end{array}$ & categorical & \\
\hline Major Treaty ${ }_{i, j}$ & $\begin{array}{l}\text { Dummy variable which takes the value one when a case was de- } \\
\text { cided bv CJEU in year } j \text { in which one of the major treaties was } \\
\text { signed }\end{array}$ & categorical & NA \\
\hline Single European Act ${ }_{i, j}$ & $\begin{array}{l}\text { Dummy variable which takes the value one when a case was de- } \\
\text { cided bv CJEU in year } j \text { in which the Single European Act was } \\
\text { signed }\end{array}$ & categorical & $\mathrm{NA}$ \\
\hline Maastricht $_{i, j}$ & $\begin{array}{l}\text { Dummy variable which takes the value one when a case was de- } \\
\text { cided bv CJEU in year } j \text { in which the Maastricht Treaty was signed }\end{array}$ & categorical & NA \\
\hline Amsterdam $_{i, j}$ & $\begin{array}{l}\text { Dummy variable which takes the value one when a case was de- } \\
\text { cided bv CJEU in year } j \text { in which the Amsterdam Treaty was } \\
\text { signed }\end{array}$ & categorical & NA \\
\hline Charter of Fundamental Rights $i, j$ & $\begin{array}{l}\text { Dummy variable which takes the value one when a case was de- } \\
\text { cided bv CJEU in year } j \text { in which the Charter of Fundamental } \\
\text { Rights of the European Union was signed }\end{array}$ & categorical & NA \\
\hline Nice $_{i, j}$ & $\begin{array}{l}\text { Dummy variable which takes the value one when a case was de- } \\
\text { cided bv CJEU in year } j \text { in which the Single European Act was } \\
\text { signed }\end{array}$ & categorical & NA \\
\hline Constitution $_{i, j}$ & $\begin{array}{l}\text { Dummy variable which takes the value one when a case was de- } \\
\text { cided bv CJEU in year } j \text { in which the Constitutional Treaty was } \\
\text { signed }\end{array}$ & categorical & NA \\
\hline Lisbon $_{i, j}$ & $\begin{array}{l}\text { Dummy variable which takes the value one when a case was de- } \\
\text { cided bv CJEU in year } j \text { in which the Lisbon Treaty was signed }\end{array}$ & categorical & NA \\
\hline${\mathrm{AG}-\mathrm{ECJ}_{i, j}}$ & $\begin{array}{l}\text { Dummy variable which takes the value one whether the CJEU and } \\
\text { Advocate General agreed in year } j\end{array}$ & categorical & NA \\
\hline $\mathrm{SSI}_{i, j}$ & $\begin{array}{l}\text { A proportion of time a member state } i \text { is pivotal in year } j \text { under } \\
\text { qualified majority in the Council of Ministers }\end{array}$ & continuous & Bilbao et al. (2002) \\
\hline Efficiency $_{i}$ & $\begin{array}{l}\text { The efficiency of the public sector in member state } i \text { (Public- } \\
\text { State Performance Index from the Global Competitiveness Rank- } \\
\text { ing 2017-2018) }\end{array}$ & ordinal & $\begin{array}{l}\text { World Economic Forum } \\
(2017)\end{array}$ \\
\hline
\end{tabular}

Note: NA means that no data source is necessary to compile the variable 
Table 4: Coefficients of Test 1, 2 and 3 applying Bayesian Estimation

\begin{tabular}{|c|c|c|c|c|c|c|c|c|c|c|c|c|c|c|c|c|c|c|}
\hline & \multicolumn{18}{|c|}{ Dependent variable: } \\
\hline & \multicolumn{18}{|c|}{ Ruling } \\
\hline & \multicolumn{6}{|c|}{ Year Treaty Signature } & \multicolumn{6}{|c|}{ Year Treaty Negotiation End } & \multicolumn{6}{|c|}{ Last Stage of Treaty Negotiation } \\
\hline & \multicolumn{3}{|c|}{ I (a) } & \multicolumn{3}{|c|}{ I (b) } & \multicolumn{3}{|c|}{ II (c) } & \multicolumn{3}{|c|}{ II (d) } & \multicolumn{3}{|c|}{ III (e) } & \multicolumn{3}{|c|}{ III (f) } \\
\hline & Post.mean & $1-95 \%$ CI & $\mathrm{u}-95 \% \mathrm{CI}$ & Post.mean & $1-95 \%$ CI & $\mathrm{u}-95 \% \mathrm{CI}$ & Post.mean & $1-95 \%$ CI & $\mathrm{u}-95 \% \mathrm{CI}$ & Post.mean & $1-95 \% \mathrm{CI}$ & $\mathrm{u}-95 \% \mathrm{CI}$ & Post.mean & $1-95 \% \mathrm{CI}$ & $\mathrm{u}-95 \% \mathrm{CI}$ & Post.mean & $1-95 \% \mathrm{CI}$ & $\mathrm{u}-95 \% \mathrm{CI}$ \\
\hline Intercept & 0.333 & -1.321 & 1.69 & 0.379 & -1.4 & 1.759 & 0.291 & -1.431 & 1.617 & 0.292 & -1.441 & 1.651 & 0.387 & -1.225 & 1.759 & 0.363 & -1.352 & 1.67 \\
\hline Major Treaty & -0.557 & -0.981 & -0.119 & - & - & - & -0.317 & -0.729 & 0.114 & - & - & - & -0.584 & -1.068 & -0.072 & - & - & - \\
\hline Single European Act & - & - & - & -0.629 & -1.599 & 0.491 & - & - & - & -0.04 & -1.296 & 1.445 & - & - & - & -1.343 & -2.794 & 0.278 \\
\hline Maastricht & - & - & - & -1.147 & -1.878 & -0.383 & - & - & - & -0.21 & -1.029 & 0.782 & - & - & - & -0.217 & -1.338 & 1.063 \\
\hline Amsterdam & - & - & - & -0.311 & -1.223 & 0.729 & - & - & - & -0.238 & -1.135 & 0.764 & - & - & - & -0.962 & -2.046 & 0.272 \\
\hline Nice & - & - & - & 0.292 & -0.619 & 1.355 & - & - & - & 0.492 & -0.523 & 1.691 & - & - & - & 0.27 & -0.747 & 1.495 \\
\hline Constitution & - & - & - & -0.557 & -1.395 & 0.351 & - & - & - & -0.503 & -1.319 & 0.42 & & - & - & -0.862 & -1.769 & 0.114 \\
\hline Lisbon & - & - & - & -0.881 & -1.725 & 0.027 & - & - & - & -0.814 & -1.624 & 0.062 & - & - & - & -0.403 & -1.577 & 0.967 \\
\hline AG-ECJ & 2.572 & 2.092 & 3.052 & 2.564 & 2.066 & 3.076 & 2.58 & 2.085 & 3.08 & 2.587 & 2.081 & 3.098 & 2.549 & 2.045 & 3.064 & 2.57 & 2.075 & 3.074 \\
\hline SSI & 1.348 & -2.53 & 6.257 & 1.081 & -2.913 & 6.146 & 1.284 & -2.497 & 6.407 & 0.853 & -3.009 & 5.83 & 1.068 & -2.68 & 5.783 & 1.111 & -2.641 & 5.838 \\
\hline Efficiency & -0.13 & -0.442 & 0.216 & -0.126 & -0.436 & 0.249 & -0.129 & -0.43 & 0.234 & -0.122 & -0.427 & 0.236 & -0.14 & -0.445 & 0.191 & -0.141 & -0.433 & 0.213 \\
\hline$\underline{\sigma_{i}}$ & 0.360 & 0.001 & 1.080 & 0.390 & 0.020 & 1.160 & 0.360 & 0.020 & 1.080 & 0.360 & 0.010 & 1.110 & 0.350 & 0.010 & 1.070 & 0.340 & 0.010 & 1.040 \\
\hline WAIC & & 838.78 & & & 839.67 & & & 842.61 & & & 848.97 & & & 839.83 & & & 844.26 & \\
\hline$R_{g l m m(m)}^{2}$ & & 0.930 & & & 0.903 & & & 0.925 & & & 0.855 & & & 0.896 & & & 0.923 & \\
\hline$\underline{R_{g l m m(c)}^{2}}$ & & 0.965 & & & 0.951 & & & 0.962 & & & 0.926 & & & 0.947 & & & 0.961 & \\
\hline Number of iterations & & & & & & & & & 100 & 000 & & & & & & & & \\
\hline Number of country levels & & & & & & & & & 2 & 4 & & & & & & & & \\
\hline Original sample size & & & & & & & & & 13 & 25 & & & & & & & & \\
\hline
\end{tabular}




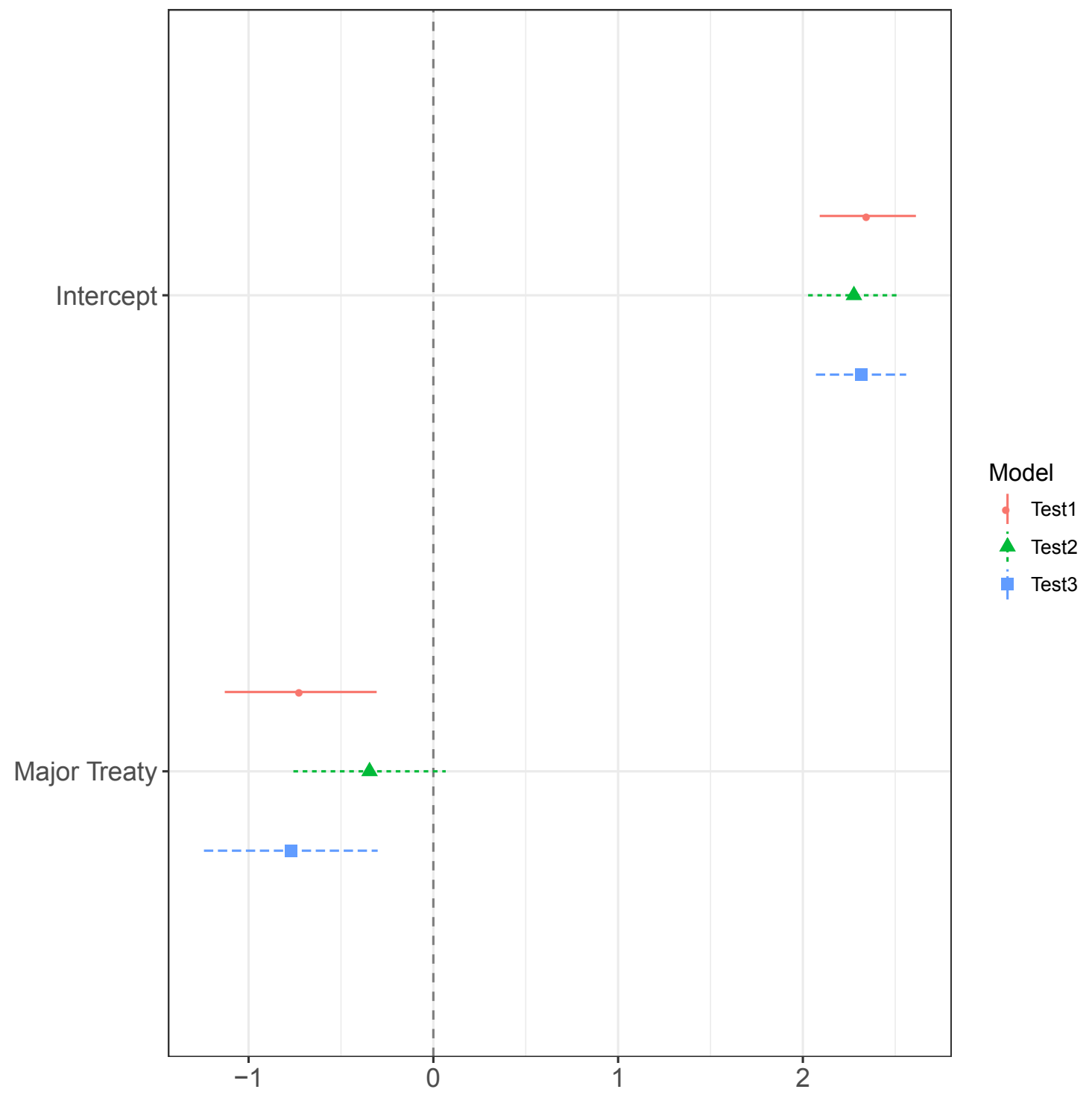

Figure 7: Estimates of equation (1) without covariates for three operationalisations of independent variable MajorTreaty. Plot shows posterior mean and 95\% confidence intervals. 


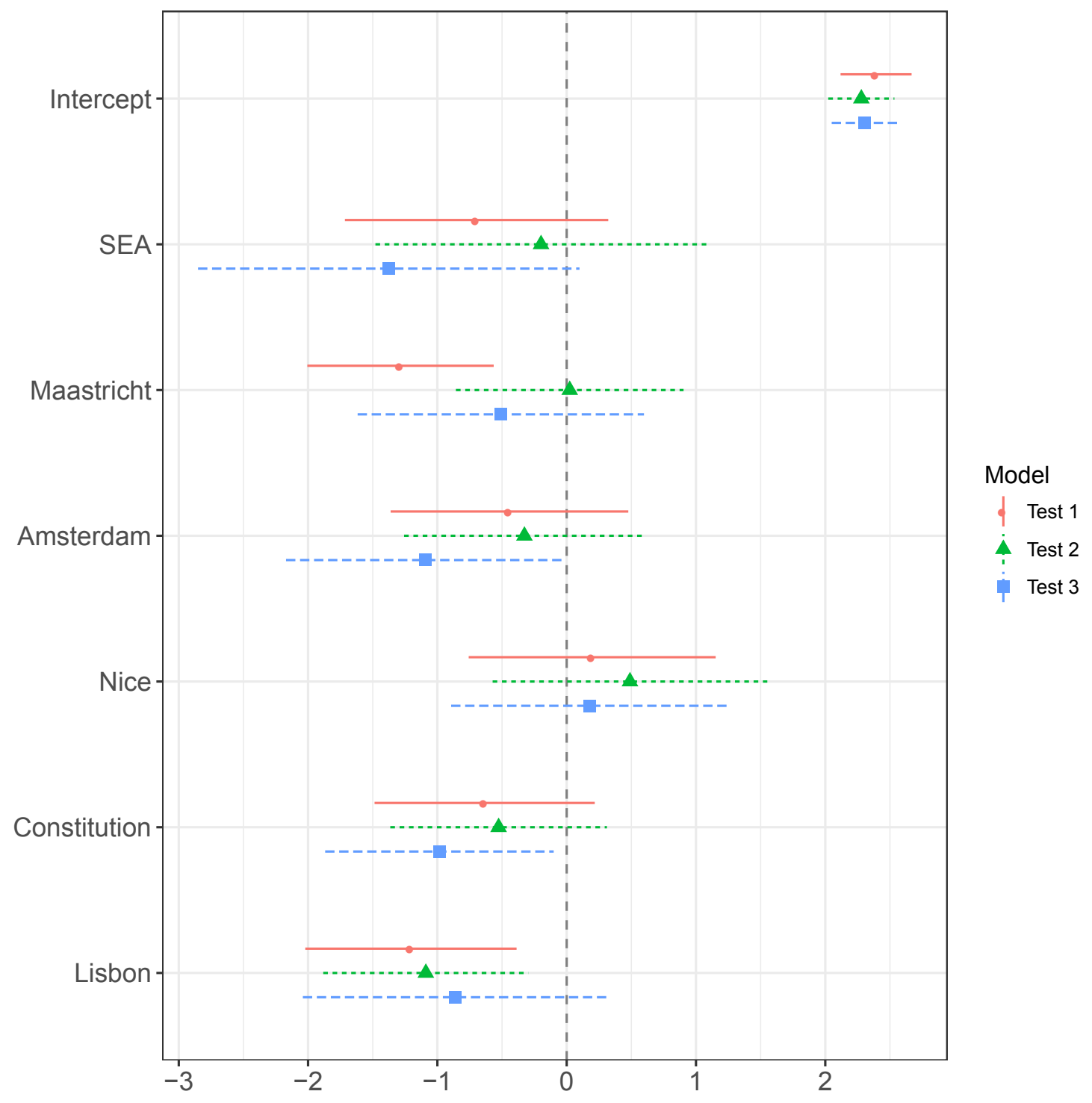

Figure 8: Estimates of equation (2) without covariates. Plot shows posterior mean and $95 \%$ confidence intervals. 


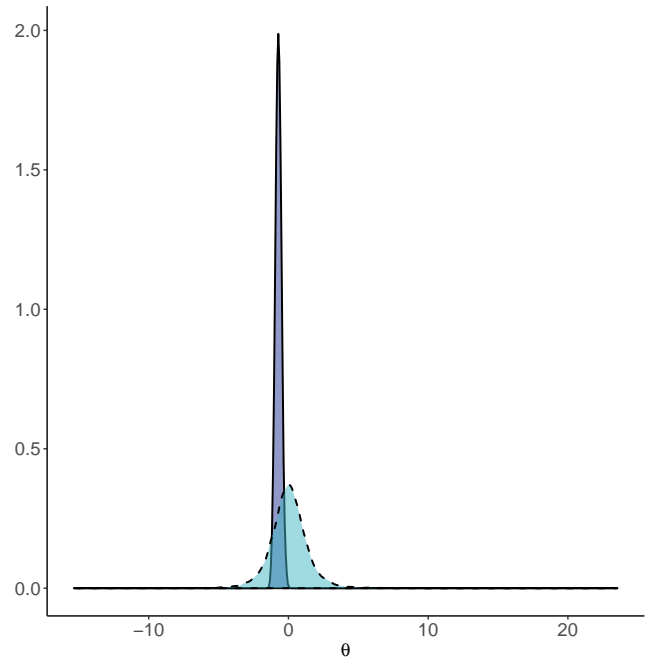

(a) Year treaty signature (Test 1)

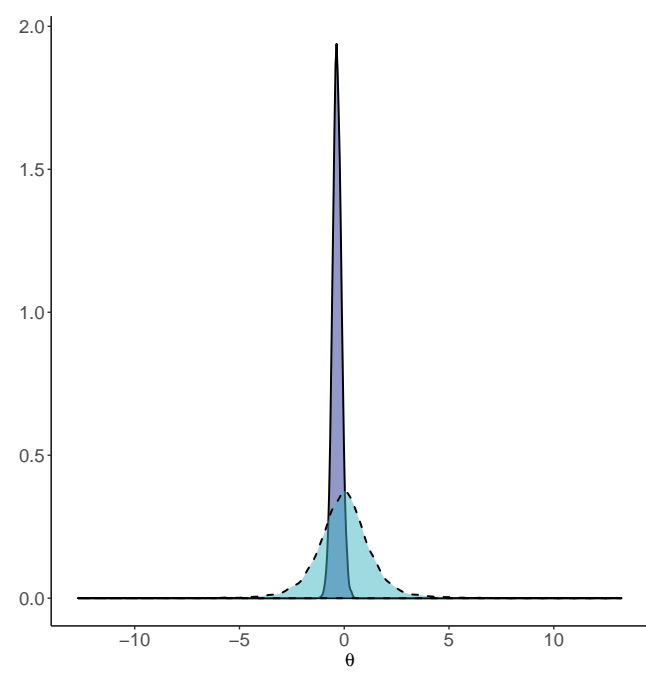

(b) Year negotiations end (Test 2)

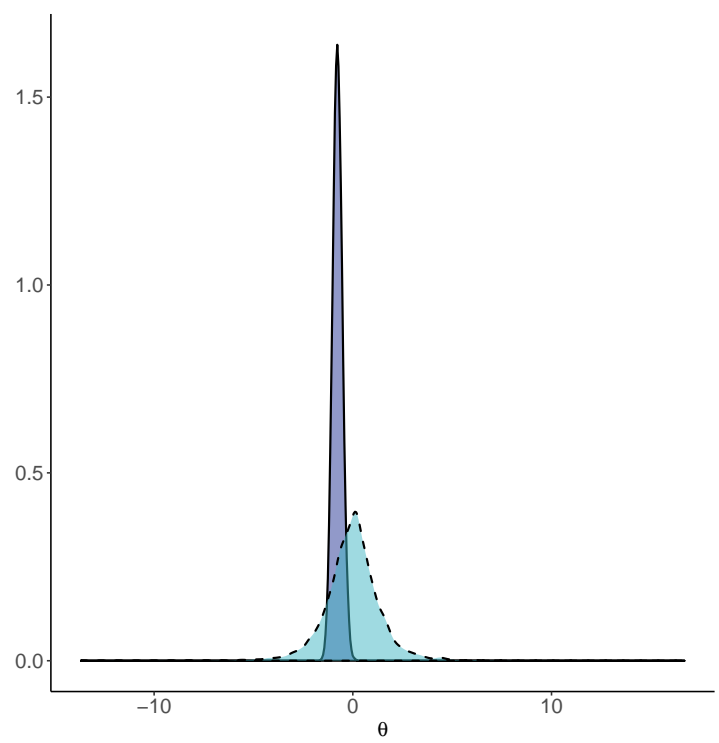

(c) Four months to treaty signature (Test 3)

Figure 9: Comparison of posterior and prior distribution of estimated effect of treaty revision on probability to rule against member state governments without covariates. The three panels correspond to the three main operationalisations of our independent variable. Dashed curve denotes prior distribution. 
Table 5: Log-odds of Maximum Likelihood Estimation excluding Advocate General

Dependent variable:

Ruling

Year Treaty Signature Year Treaty Negotiation End Last Stage of Treaty Reform

(b)

\begin{tabular}{lccc} 
& (a) & $(\mathrm{b})$ & $(\mathrm{c})$ \\
\hline Constant & $2.865^{* * *}$ & $2.842^{* * *}$ & $2.916^{* * *}$ \\
& $(0.450)$ & $(0.451)$ & $(0.453)$ \\
Major Treaty & $-0.549^{* * *}$ & -0.252 & $-0.661^{* * *}$ \\
& $(0.206)$ & $(0.205)$ & $(0.234)$ \\
SSI & -0.443 & -0.537 & -0.744 \\
& $(1.980)$ & $(1.959)$ & $(1.979)$ \\
Efficiency & $-0.162^{*}$ & $-0.169^{*}$ & $-0.174^{*}$ \\
& $(0.092)$ & $(0.092)$ & $(0.092)$ \\
\hline & & & 1,360 \\
Observations & 1,360 & 1,360 & -462.504 \\
Log Likelihood & -462.807 & -465.398 & 935.009 \\
Akaike Inf. Crit. & 935.613 & 940.796 & 961.085 \\
Bayesian Inf. Crit. & 961.690 & 966.872 & \\
\hline \hline
\end{tabular}

Note: ${ }^{*} \mathrm{p}<0.1 ;{ }^{* *} \mathrm{p}<0.05 ;{ }^{* * *} \mathrm{p}<0.01$ 
Table 6: Log-Odds of Multi Level Model with Maximum Likelihood Estimation

\begin{tabular}{|c|c|c|c|c|c|c|}
\hline & \multicolumn{6}{|c|}{ Dependent variable: } \\
\hline & \multicolumn{6}{|c|}{ Ruling } \\
\hline & \multicolumn{2}{|c|}{ Year Treaty Signature } & \multicolumn{2}{|c|}{ Year Treaty Negotiation End } & \multicolumn{2}{|c|}{ Last Stage of Treaty Reform } \\
\hline & (Ia) & (Ib) & (IIc) & (IId) & (IIIe) & (IIIf) \\
\hline \multirow[t]{2}{*}{ Constant } & 0.533 & 0.663 & 0.501 & 0.568 & 0.563 & 0.581 \\
\hline & $(0.524)$ & $(0.527)$ & $(0.524)$ & $(0.527)$ & $(0.525)$ & $(0.526)$ \\
\hline \multirow[t]{2}{*}{ Major Treaty } & $-0.574^{* * *}$ & & -0.340 & & $-0.614^{* *}$ & \\
\hline & $(0.220)$ & & $(0.218)$ & & $(0.252)$ & \\
\hline \multirow[t]{2}{*}{ Single European Act } & & -0.730 & & -0.143 & & $-1.598^{* *}$ \\
\hline & & $(0.534)$ & & $(0.687)$ & & $(0.769)$ \\
\hline \multirow[t]{2}{*}{ Maastricht } & & $-1.160^{* * *}$ & & -0.271 & & -0.329 \\
\hline & & $(0.380)$ & & $(0.446)$ & & $(0.618)$ \\
\hline \multirow[t]{2}{*}{ Amsterdam } & & -0.418 & & -0.336 & & $-1.097^{*}$ \\
\hline & & $(0.480)$ & & $(0.480)$ & & $(0.567)$ \\
\hline \multirow[t]{2}{*}{ Nice } & & 0.183 & & 0.368 & & 0.136 \\
\hline & & $(0.494)$ & & $(0.547)$ & & $(0.557)$ \\
\hline \multirow[t]{2}{*}{ Constitution } & & -0.678 & & -0.605 & & $-0.984^{* *}$ \\
\hline & & $(0.435)$ & & $(0.434)$ & & $(0.472)$ \\
\hline \multirow[t]{2}{*}{ Lisbon } & & $-0.964^{* *}$ & & $-0.892^{* *}$ & & -0.504 \\
\hline & & $(0.437)$ & & $(0.437)$ & & $(0.652)$ \\
\hline \multirow[t]{2}{*}{ AG-ECJ } & $2.544^{* * *}$ & $2.524^{* * *}$ & $2.557^{* * *}$ & $2.541^{* * *}$ & $2.524^{* * *}$ & $2.529^{* * *}$ \\
\hline & $(0.247)$ & $(0.250)$ & $(0.247)$ & $(0.249)$ & $(0.247)$ & $(0.249)$ \\
\hline \multirow[t]{2}{*}{ SSI } & 0.214 & -0.414 & 0.085 & -0.579 & -0.062 & -0.015 \\
\hline & $(2.094)$ & $(2.153)$ & $(2.080)$ & $(2.149)$ & $(2.089)$ & $(2.122)$ \\
\hline \multirow[t]{2}{*}{ Efficiency } & -0.149 & -0.155 & -0.152 & -0.151 & -0.155 & $-0.162^{*}$ \\
\hline & $(0.098)$ & $(0.097)$ & $(0.098)$ & $(0.097)$ & $(0.098)$ & $(0.098)$ \\
\hline Observations & 1,360 & 1,360 & 1,360 & 1,360 & 1,360 & 1,360 \\
\hline Log Likelihood & -414.371 & -410.012 & -416.409 & -414.365 & -414.851 & -412.196 \\
\hline Akaike Inf. Crit. & 840.742 & 842.024 & 844.819 & 850.731 & 841.702 & 846.392 \\
\hline Bayesian Inf. Crit. & 872.034 & 899.391 & 876.110 & 908.099 & 872.993 & 903.760 \\
\hline
\end{tabular}

Note: ${ }^{*} \mathrm{p}<0.1 ;{ }^{* *} \mathrm{p}<0.05 ;{ }^{* * *} \mathrm{p}<0.01$ 
Table 7: Testing Additional Model Specification

\begin{tabular}{|c|c|c|c|c|c|c|c|c|}
\hline & \multicolumn{8}{|c|}{ Dependent variable: } \\
\hline & & & & & Ruling & & & \\
\hline & \multicolumn{2}{|c|}{ Year Treaty Signature } & \multicolumn{2}{|c|}{ Year Treaty Negotiation End } & \multicolumn{2}{|c|}{ Last Stage of Treaty Negotiation } & \multicolumn{2}{|c|}{ Last Stage of Treaty Ratification } \\
\hline & (1) & (2) & (3) & (4) & (5) & (6) & (7) & (8) \\
\hline \multirow[t]{2}{*}{ Constant } & 0.533 & 0.648 & 0.498 & 0.468 & 0.563 & 0.569 & 0.417 & 0.414 \\
\hline & $(0.524)$ & $(0.527)$ & $(0.523)$ & $(0.524)$ & $(0.525)$ & $(0.527)$ & $(0.521)$ & $(0.526)$ \\
\hline \multirow[t]{2}{*}{ Major Treaty } & $-0.574^{* * *}$ & & -0.335 & & $-0.614^{* *}$ & & $0.396^{*}$ & \\
\hline & $(0.220)$ & & $(0.218)$ & & $(0.252)$ & & $(0.221)$ & \\
\hline \multirow[t]{2}{*}{ Merger } & & 20.486 & & 20.874 & & & & 18.688 \\
\hline & & (109098) & & $(362039)$ & & & & $(35695)$ \\
\hline \multirow[t]{2}{*}{ Single European Act } & & -0.715 & & -0.140 & & $-1.599^{* *}$ & & -0.470 \\
\hline & & $(0.535)$ & & $(0.687)$ & & $(0.769)$ & & $(0.480)$ \\
\hline \multirow[t]{2}{*}{ Maastricht } & & $-1.145^{* * *}$ & & -0.270 & & -0.329 & & -0.109 \\
\hline & & $(0.381)$ & & $(0.446)$ & & $(0.618)$ & & $(0.503)$ \\
\hline \multirow[t]{2}{*}{ Amsterdam } & & -0.402 & & -0.335 & & $-1.098^{*}$ & & $2.242^{* *}$ \\
\hline & & $(0.480)$ & & $(0.480)$ & & $(0.567)$ & & $(1.037)$ \\
\hline \multirow[t]{2}{*}{ Charter of Fundamental Rights } & & 0.304 & & 0.368 & & 0.825 & & 0.598 \\
\hline & & $(0.548)$ & & $(0.547)$ & & $(1.245)$ & & $(0.545)$ \\
\hline \multirow[t]{2}{*}{ Nice } & & 0.198 & & & & -0.521 & & $1.026^{* *}$ \\
\hline & & $(0.494)$ & & & & $(1.076)$ & & $(0.479)$ \\
\hline \multirow[t]{2}{*}{ Constitution } & & -0.664 & & -0.605 & & $-0.983^{* *}$ & & 0.694 \\
\hline & & $(0.435)$ & & $(0.433)$ & & $(0.472)$ & & $(0.635)$ \\
\hline \multirow[t]{2}{*}{ Lisbon } & & $-0.949^{* *}$ & & $-0.892^{* *}$ & & -0.503 & & $-1.052^{* *}$ \\
\hline & & $(0.438)$ & & $(0.437)$ & & $(0.654)$ & & $(0.491)$ \\
\hline \multirow[t]{2}{*}{ AG-ECJ } & $2.544^{* * *}$ & $2.519^{* * *}$ & $2.557^{* * *}$ & $2.545^{* * *}$ & $2.524^{* * *}$ & $2.535^{* * *}$ & $2.510^{* * *}$ & $2.507^{* * *}$ \\
\hline & $(0.247)$ & $(0.250)$ & $(0.247)$ & $(0.248)$ & $(0.247)$ & $(0.249)$ & $(0.246)$ & $(0.253)$ \\
\hline \multirow[t]{2}{*}{ SSI } & 0.214 & -0.429 & 0.095 & 0.012 & -0.062 & 0.024 & 0.284 & 0.465 \\
\hline & $(2.094)$ & $(2.156)$ & $(2.079)$ & $(2.117)$ & $(2.089)$ & $(2.125)$ & (2.074) & $(2.094)$ \\
\hline \multirow[t]{2}{*}{ Efficiency } & -0.149 & -0.153 & -0.151 & -0.151 & -0.155 & -0.161 & -0.150 & $-0.174^{*}$ \\
\hline & $(0.098)$ & $(0.097)$ & $(0.098)$ & $(0.098)$ & $(0.098)$ & $(0.098)$ & $(0.098)$ & $(0.098)$ \\
\hline Observations & 1,360 & 1,360 & 1,360 & 1,360 & 1,360 & 1,360 & 1,360 & 1,360 \\
\hline Log Likelihood & -414.371 & -409.784 & -416.441 & -416.114 & -414.851 & -412.000 & -414.813 & -405.489 \\
\hline Akaike Inf. Crit. & 840.742 & 845.567 & 844.882 & 854.229 & 841.702 & 847.999 & 841.626 & 836.978 \\
\hline Bayesian Inf. Crit. & 872.034 & 913.365 & 876.173 & 911.596 & 872.993 & 910.582 & 872.917 & 904.776 \\
\hline
\end{tabular}

Note: ${ }^{*} \mathrm{p}<0.1 ;{ }^{* *} \mathrm{p}<0.05 ;{ }^{* * * *} \mathrm{p}<0.01$ 


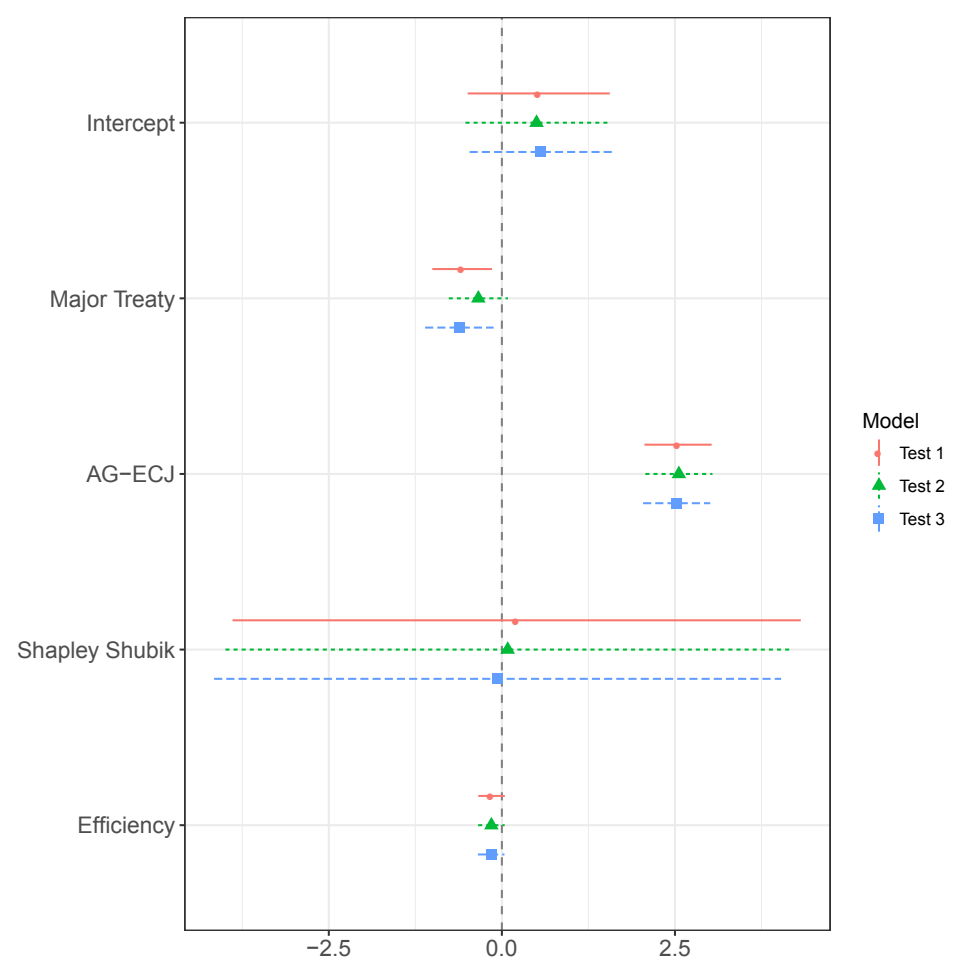

(a) Estimating equation (1)

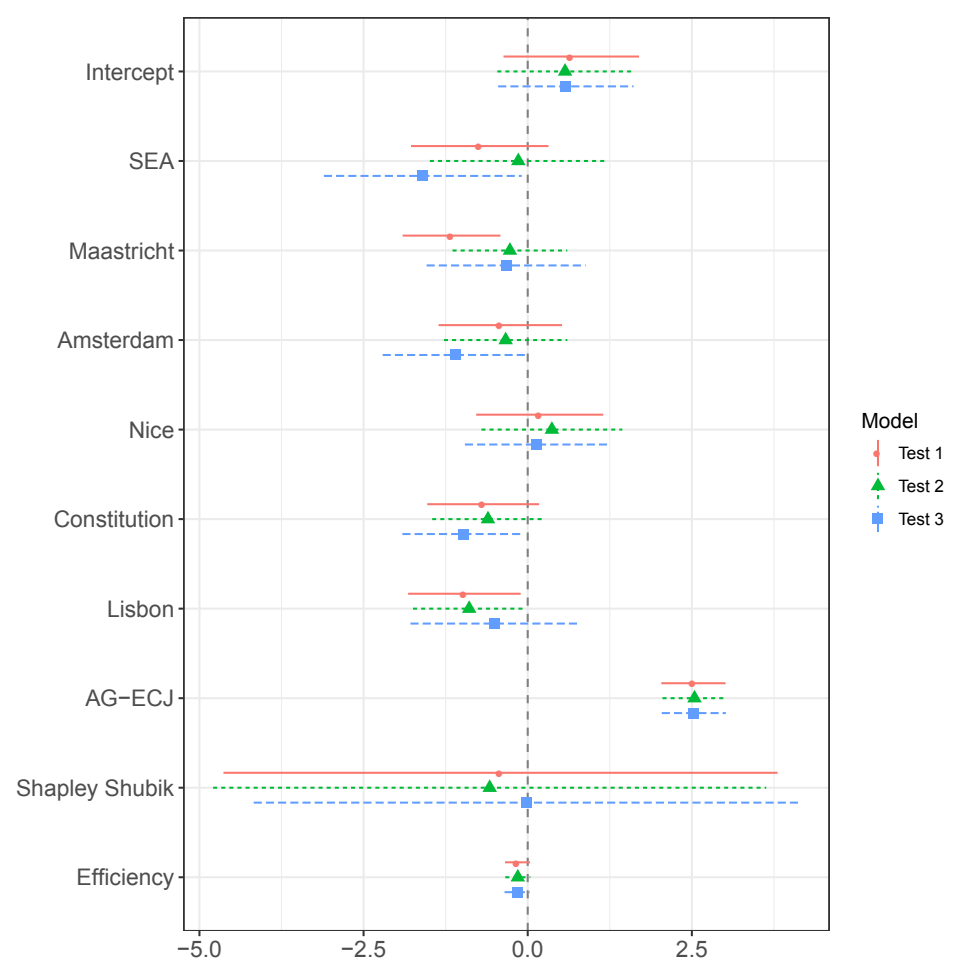

(b) Estimating equation (2)

Figure 10: Plotting the Coefficients and 95\% Confidence Intervals 


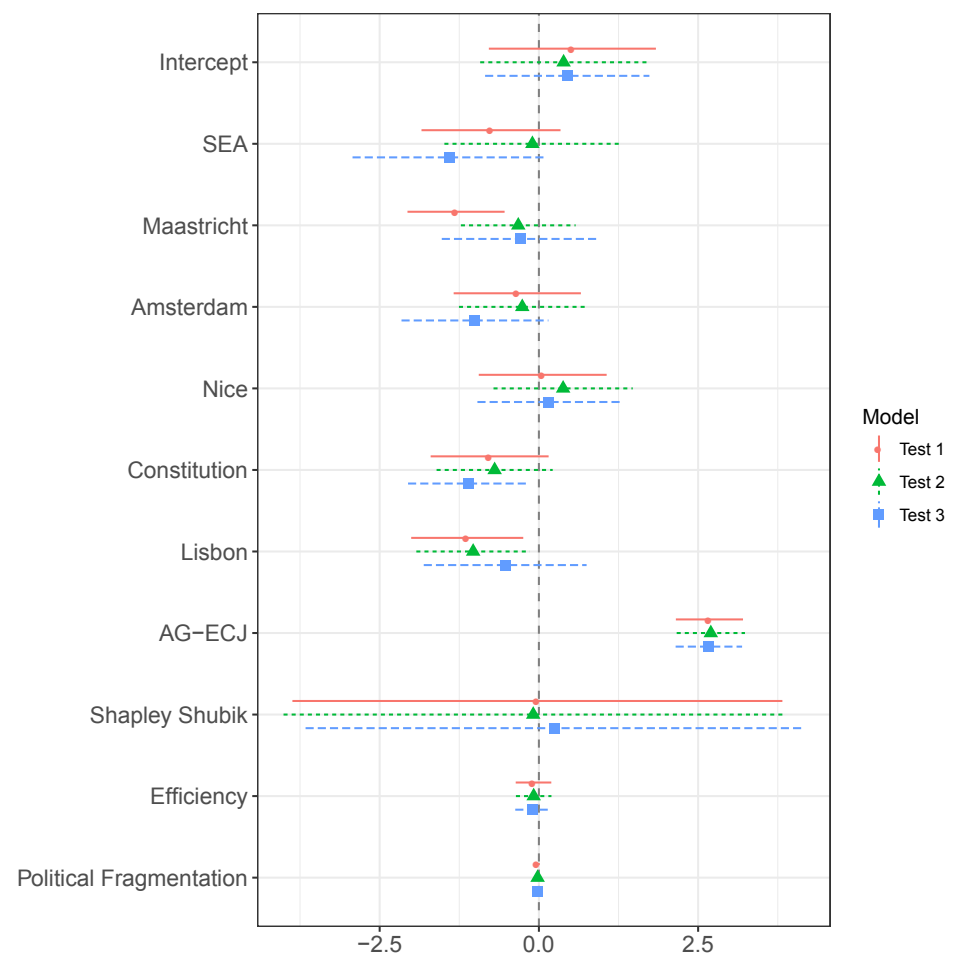

(a) Estimating equation (1) including veto players

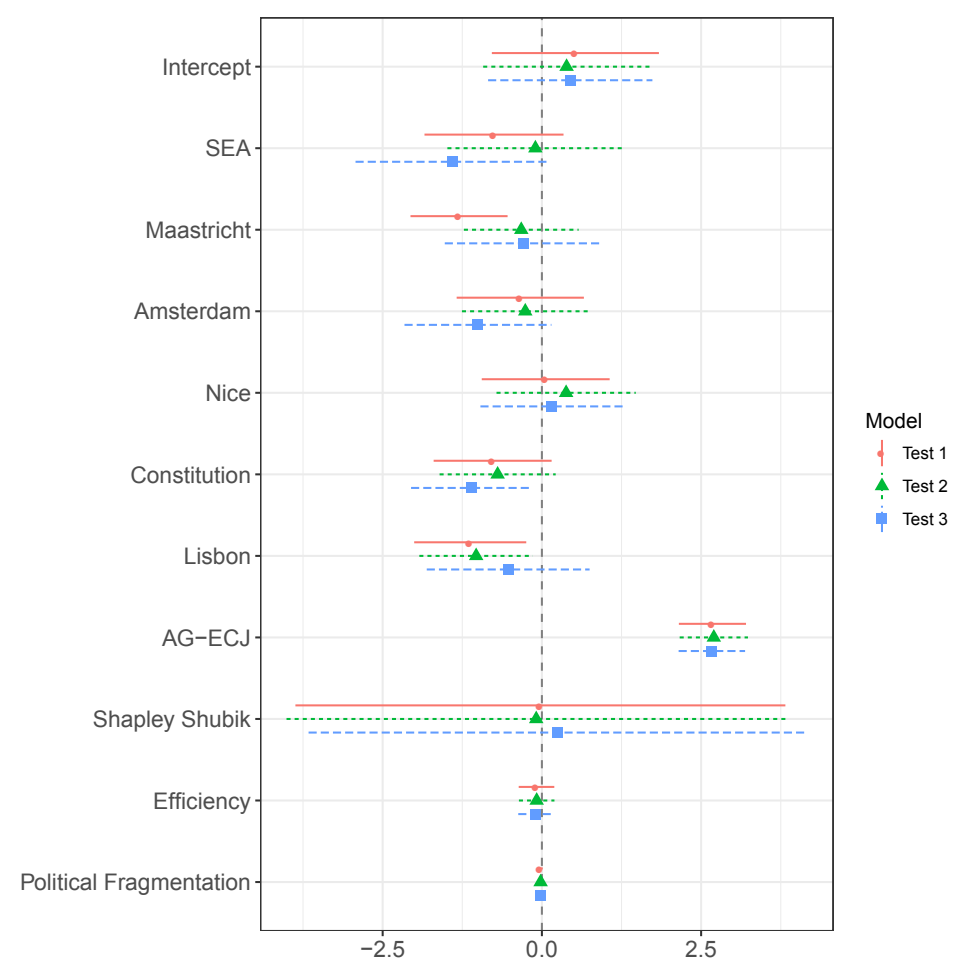

(b) Estimating equation (2) including veto players

Figure 11: Plotting the posterior mean and 95\% confidence intervals for models with different operationalisation and including the control variable veto players 